\title{
CONSTRAINTS FROM GRANITIC PLUTONISM ON PROTEROZOIC CRUSTAL GROWTH OF THE TRANSVERSE ZONE, BORBOREMA PROVINCE, NE BRAZIL
}

\author{
EDILTON J. SANTOS \& VLADIMIR C. MEDEIROS
}

\begin{abstract}
RESUMO EVIDÊNCIAS DE ACRESÇÃO CRUSTAL PROTEROZÓICA A PARTIR DE PLUTONISMO GRANÍTICO NA ZONA TRANSVERSAL DA PROVINCIA BORBOREMA, NORDESTE DO BRASIL O domínio da zona transversal na Província Borborema compre\&Nde um mosaIcó de terrenos situado entre os lineamentos Patos e Pernambuco, os quais foram justapostos através de dois ciclos orogênIcós, um mais antigo, de idade Grenville, chamado de Cariris Velhos (1,1-0,95 Ga), e outro mais jovem, de idade Panafricana-Brasiliana (0,75-0,54 Ga). São compostos por terrenos de idades Meso e Neoproterozóica, denominados de Piancó-Alto Brígida (TPB), Alto Pajeú (TAP), Alto Moxotó (TAM) e Rio Capibaribe (TRC), nos quais desenvolveu-se um plutonismo granítico notável, coerente com a repartição dos terrenos. O plutonismo Cariris Velhos é associado a uma tectônica de escamas, sendo ausente ou desconhecido no TPB, mas abundante no TAP, que possui características de $\|$ mfold-thrust belt, e no TAM, numa ambiência de arco magmátIcó; granitóides deste ciclo, provavelmente, também ocorrem no TRC. Observa-se uma ausência de granitos brasilianos no TAM, ao passo que o limite TAP-TAM é isento de intrusivas shoshoníticas e ultrapotássicas, que são comuns nos demais limites de terrenos. Os granitos crustais colisionais Cariris Velhos do TAP contrastam com os granitos leucocrátIcós e trondhjemitos pouco evoluídos do TAM, enquanto que um plutonismo gabro-anortosítIcó e álcali-granítico paleo e mesoproterozólcó parece ser restrito ao TAM e TRC. A ocorrência de rochas máficas e ultramáficas juvenis, assim como a assinatura geoquímica e isotópica $\varepsilon N d$ de rochas vulcânicas e granitos no TAP, TAM e TRC indicam que processos acrescionários desempenharam um papel importante em certos setores dos terrenos gerados durante o ciclo Cariris Velhos. Entretanto, a atividade granítica brasiliana foi muito mais volumosa, teNdo desenvolvido possantes cordilheiras graníticas ao longo e nos limites dos terrenos. Uma super-suite calcio-alcalina nornjal e com alto $\mathrm{K}$ e uma suite trondhjemítica são características do TPB, podeNdo representar um trend evolutivo semelhante ao da série calcio-alcalina-trondhjemítica do SW da Finlândia. O ramo com alto $\mathrm{K}$ desta super-suite é bastante espalhado no TAP e TRC, sendo algumas vezes associado a granitos leucocrátIcós peraluminosos. Zircões supostamente herdados com $750 \mathrm{Ma}$ foram registrados em um plúton do TAP, sugerindo tratar-se da idade dos magmas máfIcós shoshonítIcós precursores. Os granitos dessta super-suite foram colocados no intervalo entre 620 e $630 \mathrm{Ma}$ e, com exceção da suite calcio-alcalina rica em K, possuem razão moderada ${ }^{87} \mathrm{Sr} /{ }^{86} \mathrm{Sr}$ e valor negativo baixo de $\varepsilon N d$, indicando tratar-se de magmas híbridos com componentes derivados do manto e crosta. A super-suite peralcalina ultrapotássica e shoshonítica (tardicinemática) ocorre caracteristicamente ao longo e adjacente à algumas zonas de cisalhamento que separam os terrenos, sendo aquela no limite TPB/TAP a mais imponente cordilheira granítica deste pulso. Dados da literatura indicam uma idade de colocação em torno de 566 Ma, idades modelos Nd (IDM) em torno de $2.0 \mathrm{Ga}$ e valores negativos altos de $\varepsilon N d$, sugerindo uma fonte mantélica acamadada enriquecida (Transamazônica), realçada metassomaticamente durante a orogênese Cariris Velhos. O último grande pulso granítico ocorreu por volta de 512 Ma, sendo representado pela suite granítica tipo A pós-cinemática, que se desenvolveu nas proximidades do limite TAP/TAM. Esta suite é subalcalina à levemente alcalina e possui padrões geoquímIcós de granitos anorogênicos. O plutonismo granítico brasiliano é relacionado a um regime extensional e transtensional, implicando mais em processos de dispersão translacional, do que de substanciais processos acrescionários.

Palavras-chave: Granitos, terrenos, acresção crustal, zona transversal, Província Borborema.
\end{abstract}

ABSTRACT The transverse zone in Borborema Province is a mosaic of terranes situated between the Patos and Pernambuco lineaments, which were assembled through two orogenic cycles: an early, Grenville age, the Cariris Velhos event (from 1.1 to 0.95 Ga) and a later Brasiliano event (from 0.75 to $0.54 \mathrm{Ga}$ ). It is composed by Meso- and Neoproterozoic terranes, viz. Piancó-Alto Brígida (PBT), Alto Pajeú (APT), Alto Moxoto (AMT) and Rio Capibaribe (RCT), where the granitic plutonism is a noteworthy phenomenon and presents a pattern coherent with the terrane arrangement. The Cariris Velhos plutonism is controlled by a flake tectonics regime. It is absent or unknown in PBT, but abundant in the fold-and-thrust APT, in the arc-related AMT, and also probably occurs in RCT. No Brasiliano-age granite occurs in AMT, the APT/AMT limit lacking late-kinematic shoshonitic and ultrapotassic granites and syenites that are typical of other terrane boundaries in the region. The Cariris Velhos crustal collisional granites of the APT contrasts with the little evolved granites and trondhjemites of the AMT, while Paleoproterozoic and Mesoproterozoic gabbro-anorthositic and alkali-granitic intrusions are probably restricted to AMT and RCT. The occurrence of juvenile mafic-ultramafic rocks and geochemical and isotopic data, especially $\varepsilon N d$ signatures of volcanic rocks and granites in APT, AMT and RCT, indicate that accretionary processes indeed had an important role in segments of the Cariris Velhos belts. The Brasiliano-age granitic activity was a much more voluminous phenomenon, having developed major plutonic belts in the terranes and along their boundaries. A high-K to normal calc-alkalic super-suite and a trondhjemitic suite are characteristic in the PBT and can represent an evolutionary trend similar to the calc-alkalic-trondhjemitic series of SW Finland. The high-K branch of this super-suite is widespread in APT and RCT, sometimes associated with peraluminous leucocratic granites. Probable inherited zircons with ca.750 Ma age in APT plutons suggest that this is the age of the precursor shoshonitic mafic magmas of this K-rich calc-alkalic suite. Data from the literature indicate taht these granites were emplaced in the 630-620 $\mathrm{Ma}$ age interval and, with exception of the high-K calc-alkalic suite, contain moderate initial ${ }^{87} \mathrm{Sr} /{ }^{86} \mathrm{Sr}$ ratio and low negative $\varepsilon \mathrm{Nd}$, indicating a hybrid crustal and mantle-derived source. The late-kinematic peralkalic ultrapotassic and shoshonitic super-suite occurs characteristically along and adjacent to transtensional shear zones separating some terranes, the biggest plutonic belt marking the PBT/APT limit. Data from the literature points to $566 \mathrm{Ma}$ as the age of emplacement of the ultrapotassic suite. The latest major granitic pulse (512 Ma) is the post-kinematic A-type granite suite occurring in the APT/AMT boundary. This suite is subalkalic to slightly alkalic and presents geochemical patterns similar to anorogenic granites. The Brasiliano-age granitic plutonism is related to an extensional and transtensional regime, rather implying in strike-slip dispersion than substantial accretionary processes.

Keywords: Granites, terranes, crustal growth, transverse zone, Borborema Province.

TRANSVERSE ZONE: TERRANE ARRANGEMENT, GRANITIC SUITES AND SUPER-SUITES The Borborema Province (NE Brazil) is a mosaic of microplates and fold belts that spread between the Congo/Kasai-São Francisco and São Luís-West Africa cratons (Brito Neves \& Cordani 1991, Jardim de Sá 1994, Trompette 1994). Tectonic models have in common the Brasiliano/Pan-African age of the main deformation and metamorphism but differ on the age of deposition and volcanism.

Recent investigations in the south of the Patos lineament strongly suggest mechanisms of accretion and dispersion of tectonostratigraphic terranes operating in two major cycles (Santos et al. 1995, 1996, Brito Neves et al. 1995, Van Schmus et al. 1995, Jardim de Sá et al 1992,1997): an earlier, of Grenville-age, the Cariris Velhos cycle $(1.1-0.95 \mathrm{Ga})$ and a later, the Brasiliano cycle $(0.75-0.54 \mathrm{Ga})$. Bordering the northern edge of the São Francisco craton (CSF) occur two fold and thrust belts, the Riacho do Pontal and the Sergipano belts, representing the External domain, partially underlined by cratonic basement rocks (Fig. 1). In both belts probable sutures are documented by sequences with geochemical signatures similar to oceanic and arc materials (Jardim de Sá et al. 1992, Jardim de Sá 1994), which mark the transition for domains of displaced terranes of the internal zone of the orogen. Masses of Cariris Velhos migmatites and granites were thrusted against these belts in the Brasiliano cycle forming a huge granite and high grade gneiss massif, that is known as the PernambucoAlagoas terrane (PAT).

Domains at the northern of the Pernambuco Lineament represent a collage of displaced terranes dispersed by the strike-slip-dominant Brasiliano orogenesis, involving an anastomosing system of dextral and sinistral shear zones (Jardim de Sá 1994), that result in a regional dextral movement of the terranes en échelon. The domains to the north of the Patos Lineament involve mainly alternating reworked early Precambrian blocks and ensialic Meso- and Neoproterozoic belts (Fetter et al. 1997, Jardim deSá et al 1997). In this part of the Province, the Rio Grande do Norte, Cearense and Médio Coreaú (NW Ceará) 
domains were juxtaposed each other by Neoproterozoic transcurrent shear zones. Accretion phenomena were documented mostly in the Cariris Velhos internal terranes of the transverse zone (Santos 1995). In the transverse zone we can distinguish a gneissic-migmatitic terrane in the northwestern region, and accretionary and collisional Meso- to Neoproterozoic terranes at the southeastern region (Campos Neto et al. 1994, Van Schmus et al. 1995, Santos \& Medeiros 1997, Kozuch et al. 1997). These terranes are referred to as Piancó-Alto Brfgida (Cachoeirinha-Salgueiro belt) (PBT), Alto Pajeú (APT), Alto Moxoto (AMT) and Rio Capibaribe (RCT) terranes (Fig. 1). In particular the granitic plutonism reveals contrasts that reinforce this terrane characterization (Ferreira et al. 1997a), that have also been recorded in other erogenic belts in the World (Barr 1990; Boriani et al. 1995). There are abundant data on the Neoproterozoic granites of PBT and APT but fewer on others terranes. Studies on the Mesoproterozoic granites are more limited and only recently petrographic and geochemical data have been added (Santos 1995, Sá et al. 1997).

ExteNding earlier geochemical review on granitic plutonism of the Transverse Zone (Medeiros 1995a), the present paper investigates possible relationships among the multiple associations described in this region, aiming at the recognition of a coherent genetic and tectonic framework. Geochemical and isotopic contrasts between granitoids of different terranes in the transverse zone are discussed attempting to clarify the relationship between granite formation, terrane collage and crustal growth of this part of the Province. The granites, particularly those of Brasiliano-age in the transverse zone, constitute arrays of simple and multiple intrusions and dikes trending linearly in northeastsouthwest direction assembled into major plutonic complexes, in which we believe the pulses and surges can be related genetically. Using field relations, the tectonic framework and the available petrologic and geochronological data we propose a subdivision of the granite types in suites and super-suites (or units and super-units), including both Cariris Velhos and Brasiliano granitoids.

According to Pitcher (1985 p.93) in batholiths or batholithic complexes (as the Cordilleran batholiths in North and South America), "despite the great number of separate intrusions and the wide range of lithologies there is a simple overall pattern wherein the intrusion mechanism remains constant over the entire length of the batholith, and the constituent rocks reduce to a small number of natural compositional units". In other words (Pitcher 1993), the granitic rocks group naturally into well defined consanguineous rock suites, each with its own identity as defined in terms of chronology, modal and chemical composition, textures, enclave population and dike swarm association. The regional distribution of these complexes has been described in terms of super-unit, super-suite, sequence or intrusive suite by several authors, each of the rock units making up a super-suite having a intrusive contact, so representing distinct and separate surge or pulse of magma. "Clearly the recognition of such super-suites is crucial to granite studies because it allows the identification and mapping of granites representing discrete batches of magma, each of which is likely to be unique in both origin and subsequent evolution" (Pitcher 1993,p.108).

\section{BRASILIANO GRANITIC SUITES AND SUPER-SUITE OF THE PIANCÓ-ALTO BRIGIDA TERRANE (PBT) The PBT}

composite terrane has evolved by accretion of three minor terranes: a Mesoproterozoic continental intraplate volcano-sedimentary terrane (Riacho Gravata complex); a Mesoproterozoic arc volcano-sedimentary terrane (Poço dos Cachorros complex) and a Neoproterozoic turbiditic-dominant terrane (Cachoeirinha-Olhos d'Água complex) (Campos Neto et al. 1994, Lima et al. 1996, Santos \& Medeiros 1997, Kozuch 1997). Concealed Cariris Velhos shear zones separate the Mesoproterozoic terranes, while a Brasiliano transpressional,shear belt limits both these terranes with the Cachoeirinha-Olhos d'Âgua belt. Cariris Velhos granites are not known in PBT, but orthogneiss blocks interlayered in the southern region of the PBT can be of this age. Important deep crus'tal shear zones, the Patos and Fernandes Vieira shear zones, mark the boundaries of the PBT. The Neoproterozoic granites of the PBT are the best studied of the Borborema Province (Almeida et al. 1971, Sial 1986, Mariano \& Sial 1988, Ferreira 1991, SilvaFilho et al. 1993, Ferreira et al. 1994 among others). The present interpretation considers the granite types described by these authors as related to three chemically distinct plutonic series, including a normal to high-K calc-alkalic super-suite and a trondhjemitic suite. In addition, minor plutons of silica oversaturated potassic alkali-feldspar granites (Almeida et al. 1971, Ferreira \& Sial 1986)), here referred to as Catingueira suite, occur as elongated stocks and dikes along the Patos lineament as well as being discrete intrusions and ring dikes in southwestern part of the belt.

The first super-suite is comprised of a $350 \mathrm{~km}$-long plutonic belt occurring as two parallel trends, a high-K calc-alkalic porphyritic Itaporanga suite in the northeastern part of the belt and a calc-alkalic epidote-bearing Concei9\$o suite in the southeastern one (Fig. 1). The Itaporanga suite encompasses large apparently tabular composite batholiths, formed by a dominant porphyritic granite to quartz monzonite association that it is often accompanied by an early- to syn-plutonic basic dominantly K-rich diorite and an intermediate equigranular granitic association (Mariano \& Sial 1993). The mineralogical phases of all associations are similar. The porphyritic rocks are composed of orthoclase megacrysts inverted to microcline by cooling, plagioclase, biotite, amphibole, sphene, allanite, apatite and zircon. The intermediate to mafic rocks present more calcic plagioclase and additionally clinopyroxene, partially replaced by hornblende, and stubby to acicular apatite.

The Conceição suite ext๕Nds as a myriad of small batholiths and stocks intruding Meso and Neoproterozoic supracrustal rocks along the extension of the PBT. Its mineralogy (Sial 1987; Sial 1993) includes amphibole, biotite, the omnipresent primary epidote and rare clinopyroxene, being a noteworthy phenomenon the absence of ironore minerals. Its composition varies from dominantly peraluminous tonalites to granodiorites. Rounded elongated quartz diorite enclaves are ubiquitous, occurring as enclave trains, sometimes resembling a breccia-like pattern. They are composed by plagioclase, abundant biotite and Ca-amphibole, quartz, sphene, apatite and some epidote. Tourmaline and milky quartz lumps are found within the enclaves in some plutons, the latter occurring also in host tonalites and granodiorites. Amphibolite inclusions are observed either as deep green amphibole aggregates or as fine-grained amphibolite xenoliths, sometimes forming double enclaves within the dioritic autoliths. These amphibolite inclusions show chemistry and O-isotopic signatures, $\mathrm{P}$ and $T$ ranges compatible with the characteristics for weathered ocean floor basalt as the source for the magmatic-epidote-bearing calc-alkalic granitoids, according to Sial (1993).

Medeiros (1995a), on the basis of whole-rock chemical data taken from the literature, emphasized the distinct calc-alkalic field of the Conceicao suite in the multicationic $R_{1} R_{2}$ diagram, as they have low content of alkalis, $\mathrm{Ba}, \mathrm{Sr}$ and low $\mathrm{Ba} / \mathrm{Rb}$ ratio as compared to the other suites of the PBT. The Itaporanga suite is compositionally heterogeneous and broadly corresponds to a high-K calc-alkalic series. However, the overall geochemical pattern, including ORG-normalized spidergrams and chondrite-normalized REE diagrams of both Itaporanga and Conceicao suites are similar, as can be visualized in the Figs. 2 and 3. These suites show high LILE enrichment and negative $\mathrm{Nb}$ anomalies, as is commonly observed in the calc-alkalic series of active continental margins. Their REE chondrite-normalized patterns are also similar, showing moderate LREE to HREE fractionation and a discrete negative Eu anomaly.

The Serrita suite occurs strictly in the southwestern part of the terrane, in a zone of higher metamorphic grade and adjacent to a Transamazonian basement block (the Icaigara block, Medeiros et al. 1993; Santos 1996; Sial et al., 1981). It is composed of amphibole and amphibole-biotite leucogranodiorites and leucogranites with a trondhjemitic affinity. Quartz, plagioclase and microcline represent more than $90 \%$ of the bulk composition, also occurring biotite, minor amphibole, besides titanite, zircon, apatite, magmatic epidote and rare iron ore as accessory minerals (Neves 1987; Sial et al. 1981). They correspond to a high alumina suite that is typical of continental associations (Barker 1979). Their trace element and REE patterns are unique in transverse zone (Figs. 2 and 3 ) and show a characteristic pattern LILE-enriched (chiefly $\mathrm{Ba}$ ) and strongly depleted in $\mathrm{Y}$ and HREE. In Rb vs. ( $\mathrm{Y}+\mathrm{Nb}$ ) diagram (Pearce et al 1984) the Serrita suite plots predominantly in the volcanic arc granites field (VAG) (Fig. 2). However, Neves (1987) considers that the trace element pattern of this suite reflects the composition of a dominant cumulative process, being inconsistent to any conclusions about its tectonic setting.

The potassic oversaturated alkali-feldspar granitic Catingueira suite is of a late erogenic pulse, probably of same age as the peralkalic of ultrapotassic suite of the PBT-APT boundary described in the next section. The largest intrusion is the Catingueira pluton, which is compositionally a quartz-alkali feldspar syenite with aegirine-augite and blue amphibole (Ferreira \& Sial 1986). In the Serrita trondhjemitic granite stock occurs later intrusions of aegirine-augite \pm richterite peralkalic granites and syenites containing minor amounts of magnetite and fluorite (Neves 1987, Ferreira \& Sial 1986). This suite shows a 


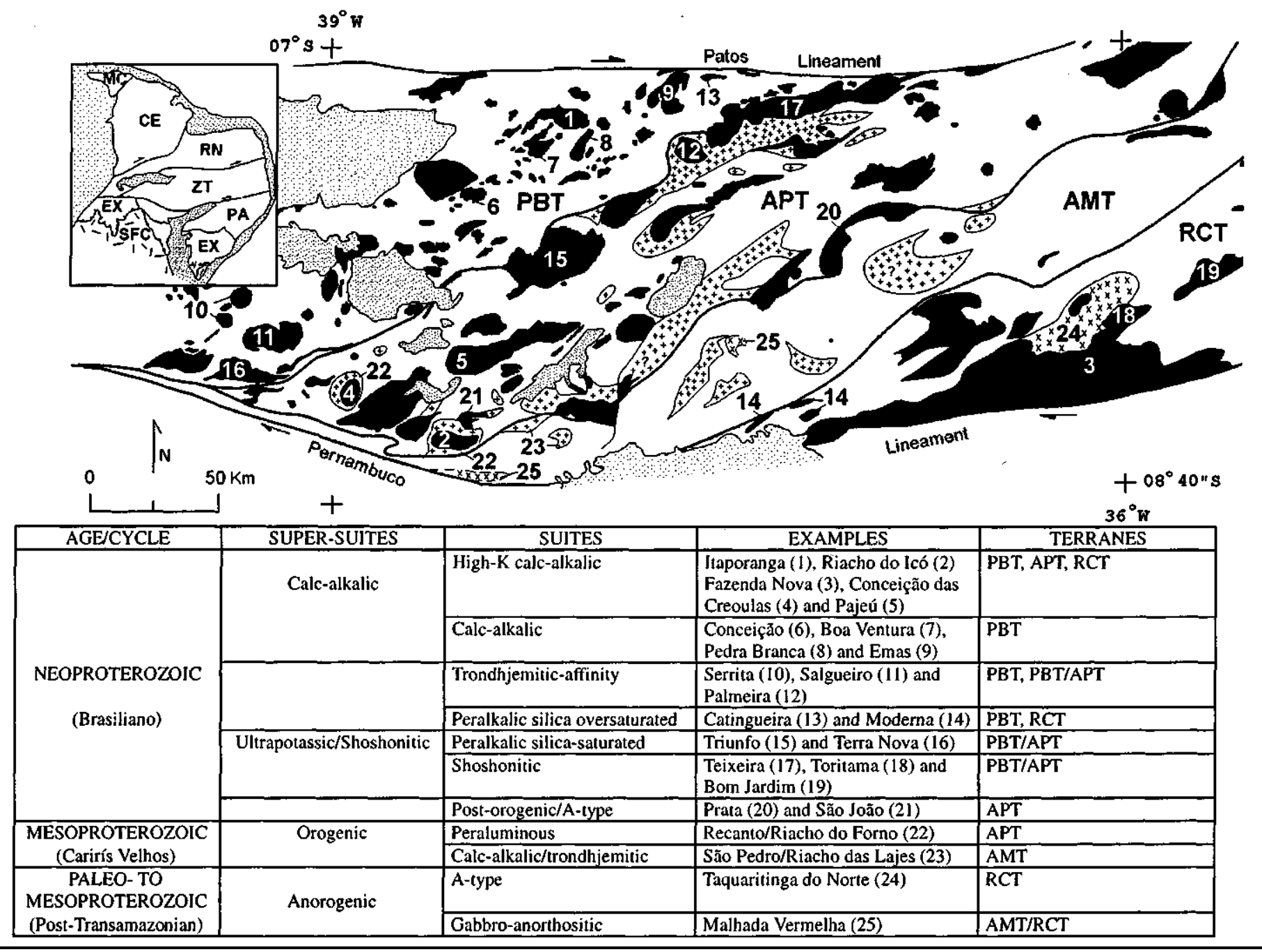

Figure 1. Schematic map of the terranes and Brasiliano-age granitoids of the Transverse Zone, northeastern Brazil. Domains adapted from Santos (1996). Stippled = Phanerozoic covers; black = Brasiliano-age granitoides; crosses = Cariris Velhos-age granitoids; Xs = anorogenic post-Transamazonian plutonic rocks. The NeoProterozoic suites are from Sial (1987), Sial \& Ferreira (1988, 1990), except for the post-orogenic/A-type, which are from Melo et al. (1995), and this work.

similar range of silica as in the Catingueira suite (around 70\%) and a major element distribution similar to the Serrita suite, except in its peralkalic character (related to a higher content of total alkalis and a lesser amount of alumina) and a lesser content of $\mathrm{FeO}_{\mathrm{T}}$. The ORG-normalized spidergrams of both associations are also similar (Fig. 2), but the rare earth elements diagram of the Serrita suite is peculiar, because it is strongly depleted in HREE (Fig. 3). The Nd isotopic evolution of the Catingueira suite is similar to that peralkalic ultrapotassic suite of the PBT-APT boundary (Fig. 4).

There is no U-Pb isotopic data for the suites described above. $\mathrm{Rb}-\mathrm{Sr}$ isochronic data indicate ages of 633 to $620 \mathrm{Ma}$ for the normal to high-K calc-alkalic super-suite (Sial et al. 1989, Sial 1993) and 557 Ma for the trondhjemitic granite suite (Silva Filho et al. 1993). This last data is inconsistent with the age normally indicated for the peralkalic ultrapotassic super-suite (around $566 \mathrm{Ma}$, according to Ferreira et al. $1997 \mathrm{~b}$ ), that cut the suite of trondhiemitic affinity. There is no field evidence of relative ages between the calc-alkalic suite and those of trondhjemitic affinity, but the latter appears to be a late-kinematic pulse, suggesting a local sodium enrichment with the time for the Brasiliano-age plutonism. Then the age of emplacement of the suite of trondhjemitic affinity must be between 630 and 566 Ma.

Some lines of evidence support a consanguineous relationship between the normal and high-K calc-alkalic suites, such as similar incompatible element patterns. The high-K calc-alkalic suite is a common series in post-Archean terranes and often occurs in plutons and batholiths associated to other calc-alkalic series (Roberts \& Clemens 1993). McMurry et al. (1987) and Mariano \& Sial (1988) have described evidence of mixing and mingling of mafic and felsic por- phyritic components in the high K-calc-alkalic suite. Isotopic signatures, including oxygen and Nd isotopes, however, do not support a cogenetic relationships between the two suites. Oxygen and strontium isotopic signatures are in agreement with the possibility of a hydrated metabasaltic source for the calc-alkalic suite as pointed by Sial (1993). Additional incorporation of aluminous metasedimentary rock, as implied by high $\delta^{18} \mathrm{O}$, can explain the high peraluminosity observed in the majority of Conceicao suite plutons. Both suites present moderate ${ }^{87} \mathrm{Sr}{ }^{86} \mathrm{Sr}$ initial ratio (0.706 to 0.707$)$, but distinct $\varepsilon N d$ values, from -1.2 to -2.0 , in the calc-alkalic, and -9 in high-K calc-alkalic suites (Van Schmus et al. 1995) (Fig. 4). These data are consistent with Roberts \& Clemens (1993) model, in which high-K calc-alkalic I-type granites originated by partial melting of older met algneous rocks. According to these authors, metabasaltic rocks are unsuitable as sources, because of their low $\mathrm{K}_{2} \mathrm{O}$ content. These source materials could have been derived from enriched subcontinental lithospheric mantle. Depending on the time elapsed and the process operating between a protolith separation from the mantle and its subsequent fusion, the granitoid magma would appear to have a more or less direct mantle connection in its isotopic signature.

This conclusion, perhaps, is suitable for high K-calc-alkalic suite of PBT since the granitoids are hosted by essentially sedimentary Neoproterozoic and older rocks, but does not apply to the calc-alkalic suite, as it had a metabasaltic source, as demonstrated by Sial (1993). Moreover the protoliths, as indicated by $t_{\mathrm{DM}} \mathrm{Nd}$ model ages, are at least of Mesoproterozoic ages. The tectonic regional control of emplacement (Jardim de Sá 1994) and absence of a subduction zone pattern for the Brasiliano-age plutonism are also consistent with this model. High 
pressure dehydration melting experiments of crustal rocks performed by Skjerlie \& Jonhston (1996) indicate that rocks containing both biotite and amphibole could potentially to produce magmas of different composition through dehydration-melting at different temperatures. If biotite goes through melting before amphibole, and if melt extraction is effective, early potassic granitoid magma could be followed at higher temperature by granodioritic-tonalitic magmas when amphibole undergoes dehydration melting.

In this environment would occurs a setting of mantle-crust source interaction recently described by Pearce (1996) as MASH (magma, assimilation, segregation, homogenization) zone. According to this author, a process of injection of mantle-derived magma into the hot crust base would produce a complex mixture of basic magma (from mantle melting), acid magma (by crustal fusion) together with basic magma crystallization products and crustal melting residues. The product would may range from evolve basalt to dacite in composition, a homogeneous melt emerging eventually from the bleNding of mantleand crust-derived magmas.

THE LATE-OROGENIC BRASILIANO SUPER-SUITE OF THE PBT-APT BOUNDARY The PBT-APT boundary is marked by a complex system of shear zones that are originally Cariris Velhos thrusts truncated or reworked by Brasiliano transcurrent shears. The Mesoproterozoic movements along these shear zones shows a transport sense in the northwesterly direction, which placed the middle to high grade APT overthrusted against the low grade PBT. Early Proterozoic blocks uplifted along this zone and a back thrusted infracrustal block emplaced inside the PBT (the Piancó nappe, according to Campos Neto et al. 1994) are typical structural features of this event. However the more evident structures are of Brasiliano age, such the Fernandes Vieira shear zone (Santos et al. 1997), that comprises of a 2 to $5 \mathrm{~km}$ of thickness of mylonitic rocks separating the greater part of two terranes. A system of anastomosing E-W dextral and NE-SW sinistral mylonitic zones reflect the major tectonic model observed in whole the transverse zone.

Large bodies of Cariris Velhos-age granites occur in the hanging wall of the main Mesoproterozoic thrust, as well as restricted Serritatype granitic intrusions. However, the most prominent feature of this boundary is a $300 \mathrm{~km}$-long ridge of late orogenic Brasiliano-age syenites and granites, which was called the "syenitoid line" by Sial (1986) and Ferreira \& Sial (1986). Actually the "syenitoid line" is the locus of a thermal zone, comprising an axial trend of elongated batholiths laterally sided by satellite intrusions, megadikes and dike sets, that cut the adjoining region in both the PBT and the APT. This plutonic association shows characteristics of mantle-derived magmas, as will be viewed later on, indicating that the shear system has penetrated very deeply into the lithosphere, these representing an important crustal boundary of the transverse zone.

Ultrapotassic and shoshonitic characteristics of this ridge have been identified in the plutonic rocks by several authors (Sial 1986; Ferreira \& Sial 1986; Ferreira 1991; Ferreira et al. 1994, 1997a,b; Silva Filho et al. 1993), which were described recently as peralkalic-ultrapotassic and epidote-bearing shoshonitic associations by Sial et al. (1997). The similarity of composition, geochemical, isotopic, geochronological nature and tectonic setting can be ascribed in terms of a peralkalic-ultrapotassic and shoshonitic super-suite.

The peralkalic ultrapotassic branch of this super-suite consists of two groups, a silica over-saturated potassic alkali-feldspar granites, already described in the previous section, and a silica-saturated ultrapotassic alkali-feldspar syenites to alkali-feldspar granites (Ferreira et al. 1994). Mainly rocks of the silica-saturated group form the syenitoid line. The alkali-feldspar syenite of the Triunfo batholith (Ferreira et al. 1992; 1994; 1995) consists of perthitic microcline and aegirine-augite as main phases, and sphene, apatite, quartz and occasional magnetite, and richterite as accessories. Alkalic pyroxenite is found as inclusions, syn-plutonic and late-stage dikes, and contains the same mineralogical phases of the syenite in different proportions. Mica pyroxenite xenoliths are composed of diopside-salite, with subordinate F-rich phlogopite, calcite, hyalophane, sphene, apatite and traces of barite. They have been regarded as fragments that were detached from the lithospheric mantle source of these magmas. Field observations, including the occurrence of rare inclusions of a "mixed" rock (about $60 \%$ syenite $+40 \%$ pyroxenite in an emulsion-like texture), and geochemical data, indicate chemical equilibrium among the three units and suggest liquid immiscibility between syenite and pyroxenite, the mixed rock representing the magma composition before splitting (Ferreira et al. 1994).
Higher $\mathrm{K}_{2} \mathrm{O}$ and lesser $\mathrm{Al}_{2} \mathrm{O}_{3}$ and $\mathrm{Na}_{2} \mathrm{O}$ than the calc-alkalic supersuite and trondhjemitic-granitic suites characterize the major element pattern of the ultrapotassic Triunfo suite. All units have an overall enrichment in incompatible elements, with negative anomalies in $\mathrm{Nb}$, $\mathrm{Sr}, \mathrm{P}$ and $\mathrm{Ti}$ in mantle-normalized trace element variation diagram. In the ORG-normalized diagram (Fig. 2) they are LILE-enriched, Ta and $\mathrm{Nb}$ (HFS)-depleted and presents an expressive negative $\mathrm{Zr}$ anomaly and similar REE chondrite-normalized pattern without Eu anomaly (Fig. 3).

The shoshonitic Teixeira granite was described by Medeiros (1995b) as an association of leucocratic amphibole granites and quartz monzonites, including a facies of biotite leucogranites, with shoshonitic affinities. It is LILE-enriched and shows a distinct positive anomaly of Ba. Both the peralkalic ultrapotassic and shoshonitic suites present somewhat similar REE patterns, the shoshonitic suite showing an overall higher REE content and a higher depletion in LREE than the ultrapotassic suite (Fig. 3). The ultrapotassic syenites plot dominantly in the UCM field, with a few samples scattered into V AG and WPG fields while the shoshonitic granites define a distinct VAG affinity (Fig. 2).

The Rb-Sr isochronic age of the Triunfo batholith is about $566 \mathrm{Ma}$ and its $t_{\mathrm{DM}} \mathrm{Nd}$ model ages is the oldest of all granites from the transverse zone (1.9 to $2.4 \mathrm{Ga}$ ) (Ferreira et al. 1997). The $\mathrm{t}_{\mathrm{DM}} \mathrm{Nd}$ model ages of the peralkalic-ultrapotassic-shoshonitic super-suite ranges from 1.8 to $2.4 \mathrm{Ga}$ and $\varepsilon N d$ from -13.5 to -16.4 . (Ferreira 1991, Van Schmus et al. 1995, Ferreira et al. 1997a), thought as consequence of a former enriched mantle-derived source reach deep along these border shear zones (Ferreira 1991) (Fig. 4).

\section{GRENVILLE- AND BRASILIANO-AGES COMPOSITE BATHOLITHS AND POST-OROGENIC GRANITES OF THE} ALTO PAJEU TERRANE (APT) The APT is comprised mainly a Mesoproterozoic greywacke-volcanoclastic terrane (São Caetano Complex, Santos et al. 1997), possibly of a continental arc environment, accreted to minor Neoproterozoic volcanic arc or back-arc sequence (Irajaí Complex, Wanderley et al. 1992). The Mesoproterozoic terrane includes tholeiitic mafic-ultramafic slices and abundant Cariris Velhos (Grenville-age) crustal collisional granites, the Riacho do Forno and Recanto suites (Santos 1995), which are well preserved as stacked sheet intrusive granitoids in a typical fold and thrust belt. The APT-AMT boundary, firstly named of "median line" by Santos \& Brito Neves (1993), is a big orthogneiss-migmatitic nappe of the Cariris Velhos cycle reworked by transpressive shears of the Brasiliano orogeny. Therefore they are upper crustal melts that are common in thickened collisional orogens (Windley 1992). The Irajaí Complex appears to be preserved as Neoproterozoic klippes above Mesoproterozoic supracrustal rocks and are associated to transpressive movements of the NE-SW Brasiliano shear zones.

The dominant facies of the Cariris Velhos plutonism are peraluminous muscovite-bearing migmatites and augen metagranitoids, which occur generally as intrusive sheets stacked along thrust surfaces of the collisional episode of this orogenic event. The Recanto metagranitoids show an augen structure and a compositional range restricted to the monzogranitic field. The mafic minerals, biotite and muscovite, are of up to $10 \%$, and the accessory minerals are garnet, titanite, apatite, allanite, zircon and rare sillimanite. The Riacho do Forno migmatites and leucogranites are more leucocratic (less of $5 \%$ of micas and accessory minerals) and more muscovite-rich than the Recanto one, exhibiting a typical migmatitic structure, of stromatic, schlieren and nebulitic types. There is not great compositional difference between these two types, but the Riacho do Forno type has some syenogranitic and alkali-feldspar granitic facies. The Recanto metagranitoids are richer in $\mathrm{TiO}_{2}, \mathrm{Ba}$ and slightly more $\mathrm{Rb}$ depleted than the Riacho do Forno ones.

These metagranitoids are moderately LILE-enriched with negative $\mathrm{Ba}, \mathrm{Nb}, \mathrm{Sr}$ and $\mathrm{Ti}$ anomalies typical of the crustal granites and very depleted in HFS elements, as consequence of its retention in accessory phases that remain in restites of the partial melting (Santos 1995). The less fractionated pattern of the ORG-normalized spidergram (Fig. 2) is somewhat similar to the syn-collision granites of Gagub (Tibet), in comparison to the patterns selected by Pearce et al. 1984. The large amount of micas confirms an origin by partial melting of Cariris Velhos supracrustal rocks, through incongruent fusion firstly of muscovite and subsequently of the biotite. This conclusion is in accordance with the Eu negative anomaly in REE diagram (Fig. 3), with the lower $\mathrm{Sr} / \mathrm{Ba}$ (Recanto: 0.1 -0.3; Riacho do Forno: 0.5) and higher $\mathrm{Rb} / \mathrm{Sr}$ ratios (Recanto: 0.9-2.8; Riacho do Forno: 1.3-2.1) than to those resulting from fluid phase reactions (Harris \& Inger 1992). Taking in to account expe- 


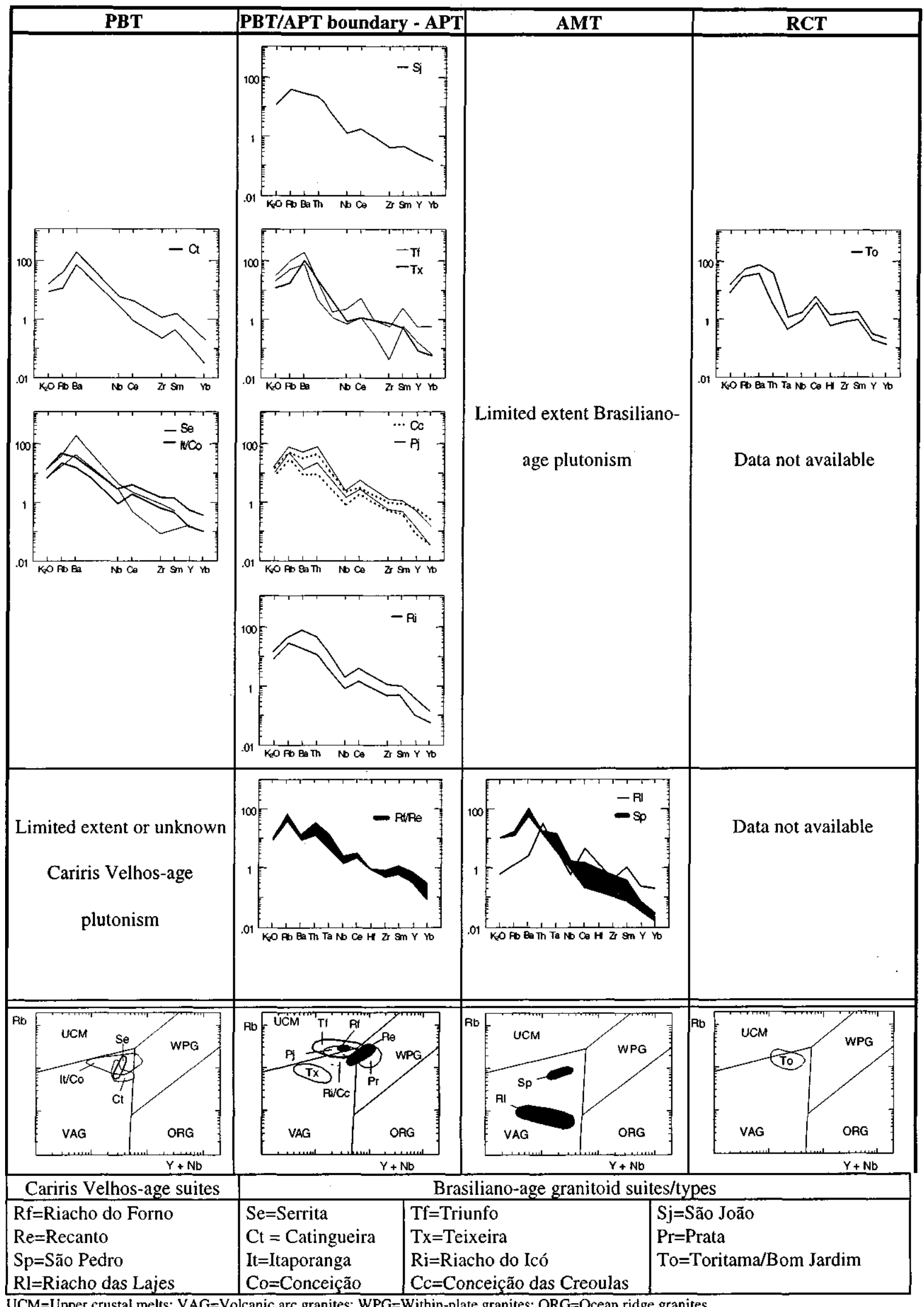

Figure 2 - Chemical characteristics of the Brasiliano- and Cariris Velhos-age granitoids of the Transversal Zone domain using Pearce et al. (1984) diagrams. Chemical analyses are from: Santas (1995; Rf, Re, Sp, Rl, Ri, Sj), Sial (1986; Se, Ct, It, Co), Ferreira (1991, Tf, Tx); Brasilino et al. (1999, Cc), Guimarães \& Silva Filho (1997, To) and Melo et al. (1996; Pr). 


\begin{tabular}{|c|c|c|c|}
\hline PBT & PBT/APT boundary - APT & AMT & $\mathbf{R C T}$ \\
\hline (1) & (1000) & $\begin{array}{l}\text { Limited extent Brasiliano- } \\
\text { age plutonism }\end{array}$ & Data not available \\
\hline $\begin{array}{l}\text { Limited extent or unknown } \\
\text { Cariris Velhos-age } \\
\text { plutonism }\end{array}$ & (1000) & (1000) & Data not available \\
\hline Cariris Velhos-age suites & \multicolumn{3}{|c|}{ Brasiliano-age granitoid suites/types } \\
\hline $\begin{array}{l}\text { Rf=Riacho do Forno } \\
\text { Re=Recanto } \\
\text { Sp=São Pedro } \\
\text { Rl=Riacho das Lajes }\end{array}$ & $\begin{array}{l}\text { Se=Serrita } \\
\mathrm{Ct}=\text { Catingueira } \\
\mathrm{It}=\mathrm{It} \text { taporanga } \\
\mathrm{Co}=\text { Conceição }\end{array}$ & $\begin{array}{l}\text { Info } \\
\text { xeira } \\
\text { cho do Icó } \\
\text { nceição das Creoulas }\end{array}$ & $\begin{array}{l}\text { ão João } \\
\text { Toritama/Bom Jardim }\end{array}$ \\
\hline
\end{tabular}

Figure 3 - Chondrite-normalized REE diagrams of the Brasiliano- and Cariris Velhos-age granitoids of the Transversal Zone domain. The normalizing values are from Evensen et al. (1978). Chemical analyses are from: Santos (1995;Rf, Re, Sp, Rl, Ri, Sj), Sial (1986; Se, Ct, It, Co), Ferreira (1991, Tf, Tx); Brasilino et al. (1999, Cc), and Guimarães \& Silva Filho (1997, To)

rimental data some authors estimate that the extensive melt formation only would occurs in temperatures around $850^{\circ} \mathrm{C}$ and pressures near $10 \mathrm{~kb}$, that is in the stage of melting of biotite, conditions only reached by introduction of extra heat, via hot basaltic magma (Pitcher 1993). The Riacho do Forno-type plots in a restrict area of the upper crustal melts field (UCM) while the Recanto-type has VAG and WPG signatures in $\mathrm{Rb}$ vs. $(\mathrm{Y}+\mathrm{Nb}$ ) diagram (Fig. 2). The Cariris Velhos metagranitoids correspond to two mica peraluminous leucogranites or crustal collisional granites associated to shear and thrust (CW or $\mathrm{C}_{\mathrm{ST}}$ types of Barbarin, 1990; 1996), that were generated by partial melting of sedimentary and volcanoclastic source in continent-continent or continent-arc collision environments. However, according to the above observations, formation of these peraluminous granitic melts would not be strictly produced by a water concentration-assisted friction mechanism along shear zones (Barbarin 1996), but must have to be enhanced by an input of mantle-derived hot material for the onset of anatexis. This input could be produced by the emplacement of hot masses of mafic-ultramafic rocks of the Serrote das Pedras Pretas suite, that are sometimes associated to these granitoids (Santos/1995).

$\mathrm{U}-\mathrm{Pb}$ concordia in zircons indicate ages ranging fron/i 1037 to 999 Ma that represent the time of formation for these granitoids (Jardim de Sá 1994; Santos 1995). The Rb-Sr isochronic ages are somewhat similar or only a little younger (954 to $915 \mathrm{Ma})$, indicating a short time for the Cariris Velhos orogeny (Brito Neves et al. 1995). Sm/Nd isotopic system data indicate $t_{\mathrm{DM}}$ model age values between 1.3 and $1.6 \mathrm{Ga}$ and $\varepsilon \mathrm{Nd}$ from -1.8 to +0.8 , suggestive for these melts of a source not exclusively crustal or of a lower crustal source with patterns close from those of the upper mantle materials. Granites in the southeast block of the Afogados da Ingazeira shear zone with similar characteristics presented U-Pb zircon ages, both by concordia and dissolution 


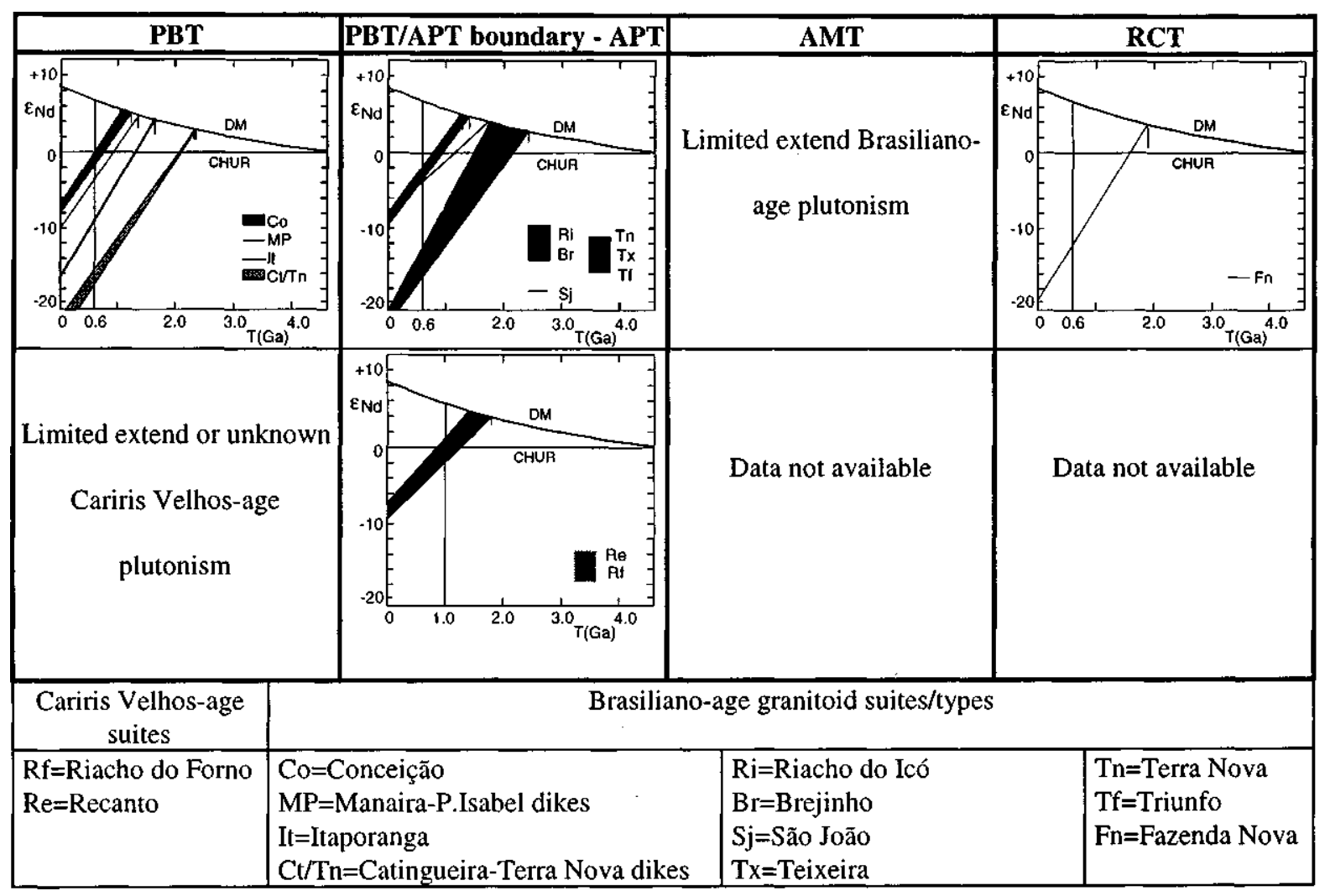

Figure 4 - Nd evolution diagram with parameters for samples of the Cariris Velhos- and Brasiliano-age granitoids from the Transversal Zone domain. Curve for the evolution of the depleted mantle (DM) from DePaolo (1981). Sm-Nd isotopic data are from Van Schmus et al. (1995, Santos (1995) and Ferreira et al. (1997c).

methods, varying from $1.9 \mathrm{Ga}$ to $1.0 \mathrm{Ga}$ (Silva et al. 1996; Leite \& Lima 1997). Field evidences, such as structural control and presence of Mesoproterozoic supracrustal xenoliths confirm they are crustal collisional Cariris Velhos granitoids, demonstrating that these melts can preserve zircons of various ages, since Transamazonian-to Cariris Velhos-age crustal sources.

Contrary to granites of the PBT, the Brasiliano granites of the APT commonly occur as multiple composite batholiths, either including Meso- and Neoproterozoic granites, or embracing diverse Neoproterozoic pulses. The dominant Neoproterozoic granites are related to the high-K calc-alkalic super-suite and include equigranular, porphyritic and leucocratic suites or surges. The equigranular fades is typified by the Riacho do Icó pluton, being here considered as a suite, in which the composition is dominantly granodioritic, but spreading between the quartz monzodiorite and monzogranite fields (Santos 1995). The mafic minerals include hornblende, biotite and occasional clinopyroxene, with minor epidote, allanite, apatite and titanite. Minor porphyritic and dioritic facies show some evidences of magma commingling and mixing phenomena, apparently similar to the high- $\mathrm{K}$ calcalkalic suite of the PBT. Mafic autoliths and microgranular enclaves are dominant, but in the internal zone of the largest pluton of this suite occurs a central roof zone with abundant supracrustal, Cariris Velhos granites and mafic-ultramafic xenoliths. The normal facies contains epidote of igneous appearance, similar to that of the calc-alkalic suite in PBT, implying in minimum pressures of crystallization around 6 kbar (e.g., Sial \& Ferreira 1991; Van der Laan \& Wyllie 1992).

The chemical composition and petrographic characteristics of these facies are similar to the hybrid "continental" arc suite of Barbarin (1990) or the sensu strict hybrid suite of Castro et al. (1991). An observed LILE enrichment, HFS elements depletion (in particular $\mathrm{Nb}$, as shown in an ORG-normalized plot, Fig. 2), moderate fractionated REE pattern with discrete Eu negative anomaly (Fig. 3) and the trace elements distribution suggest mixing and fractional crystallization involving feldspar, amphibole and biotite on evolution of these magmas. They plot around the triple junction of the UCM, VAG and WPG fields of the $\mathrm{Rb}$ vs. $\mathrm{Y}+\mathrm{Nb}$ diagram, which can indicate a heterogeneous source (Fig. 2). The Nd evolution diagrams of the Riacho do Icó granodiorite and the Brejinho pluton, are similar and resemble to the calc-alkalic super-suite of the PBT (Fig. 4).

The leucocratic granites correspond to Sítio dos Nunes suite or surge (Santos \& Vasconcelos 1977), that is formed by batholiths and stocks of normal or faulted contacts with hosted rocks and a structural pattern that is suggestive of an intrusion by diapirism with a central unroofing. The main intrusion is mainly foliated in its margin and includes enclaves of hosted rocks and enclaves surmicacées, which are concordant with this internal structure. It is compositionally restrict, being formed by monzogranite and granodiorite with less of $5 \%$ of biotite, including apatite and ore minerals as accessories. There is no geochemical data about this suite.

Apparently younger granite types occur as porphyritic high-K calc-alkalic plutons whose composition is similar to those of the APT, including the Conceição das Creoulas (Brasilino et al. 1997,1998) and Pajeú plutons (Reyes et al. 1996). They are composed of epidote-biotite granodiorites and granites with abundant monzodioritic and quartz dioritic enclaves and hornblende clots. The overall mineralogical, textural and compositional characteristics are similar to the high-K calc-alkalic super-suite of the PBT, but the Pajeú pluton includes a fine-grained syenitic facies. The ORG-normalized spidergram (Fig. 2) shows the same fractionated pattern with the $\mathrm{Nb}$ negative anomaly of the common high-K calc-alkalic series, but differs by the negative anomaly of Ba. The REE patterns (Fig. 3) are very fractionated in terms of LREE/HREE with a slight negative Eu anomaly.

A trend of peralkalic syenites and granites similar to those of the "syenitoid line" occurs in the northwestern part of the PBT, including the Serrote do Anil, Serra do Man, Serra do Arapua and part of the Pajeú plutons. Apparently this trend represents a bifurcated branch of that tectonic line that depart from the Triunfo batholith, corresponding to that which was named of Serra da Jiboia fault system by Santos et al. (1997) (Fig. 1).

Post-tectonic granites in the southeastern zone of the APT correspond to the Prata A-type suite (Melo et al. 1996), that embraces batholiths, stocks and dikes apparently controlled by a late brittle episode of the Afogados da Ingazeira shear zone. The Prata complex is formed by porphyritic and coarse grained biotite and/or hornblende sienogranites and monzogranites, minor monzodiorites, quartz mon- 
zonites and norites, including autoliths and synplutonic diorite dikes and an associated set of dacitic and basaltic dikes (Melo et al. 1995). They are met aluminous subalkalic to slightly alkalic rocks, $\mathrm{K}$ and $\mathrm{Rb}$-enriched and strongly depleted in $\mathrm{Ti}$ and $\mathrm{Sr}$. They are also depleted in $\mathrm{Nb}$, but less than other calc-alkalic suites of the Borborema Province. Their REE show small fractionation between LREE/HREE and a prominent Eu negative anomaly. According to these authors, the characteristics are very similar to Amazonian anorogenic granites and to the Jaala litti rapakivi complex in Finland. The Prata suite plots within the WPG field in the Rb vs. $(\mathrm{Y}+\mathrm{Nb})$ diagram, confirming its A-type nature (Fig. 2).

The Barra do Silva suite (Lima et al. 1985) is composed by small intrusions of leucocratic hornblende and aegirine-augite-bearing biotite granites and quartz monzonites and is considered here to be of the same age of the Prata suite. The Pitombeira semi-ring dike cutting the Pernambuco lineament confirms its post-orogenic character. Granitic and rhyolitic dikes intruding the Riacho do Icó pluton must be also of this suite. There is no geochemical data for the Barra do Silva suite.

The São João assemblage includes a stock and a set of gray and pink-colored dikes of monzogranitic composition. The main intrusion is clearly controlled by fractures. Its is compositionally homogeneous and isotropic, sometimes exhibiting a slight flow foliation. They are leucocratic rocks, presenting a granular to cataclastic hipidiomorphic texture and constituted of microcline, plagioclase, interstitial quartz and biotite, garnet, muscovite, epidote, allanite, scarce fibrolite, pyrite and apatite. The overall characteristics indicate a similarity with the intrusive crustal collisional types of Barbarin (1990). The diagrams of Figs. 2 and 3 illustrate the compositional patterns of the São João granite. It is dominantly peraluminous and shows $\mathrm{Na}_{2} \mathrm{O}>\mathrm{K}_{2} \mathrm{O}$. The trace element distribution shows a pattern similar to the calc-alkalic super-suite to the PBT (Fig. 2). The chondrite-normalized REE pattern is greatly fractionated without $\mathrm{Eu}$ anomaly. The $\mathrm{Nd}$ evolution diagram is also similar to those of the calc-alkalic of the PBT, but shows an older $t_{\mathrm{DM}}$ model age (Fig. 4).

The geochronological data for the Brasiliano granites of the APT include a U-Pb zircon age for the Riacho do Icó granodiorite of 750 $\mathrm{Ma}\left(\mathrm{t}_{\mathrm{DM}}=1.28 \mathrm{Ga}\right.$ ) (Santos 1995), that is the oldest age for the high-K calc-alkalic association in the Borborema Province. It is possible that these zircons represent inherited crystals of a basic underplated magma or of an early shoshonitic basaltic magmatism, because the main granitic episode of the Brasiliano orogeny is on the 620-633 Ma interval. A recalculated $\mathrm{Rb}-\mathrm{Sr}$ isochronic age of the Serra do Arapua pluton, using data from Lima et al. (1985), indicate an age of $585 \mathrm{Ma}$, that is the age of the majority of the late-orogenic pulses. The age of the post-tectonic pulse was documented by a $\mathrm{Rb}$-Sr isochron of 512 Ma for the Prata granite (Melo et al. 1996). This age is similar to an isochronic age of $515 \mathrm{Ma}$ that was obtained for green facies of the ultrapotassic dikes of the Terra Nova complex (Silva Filho \& Guimaraes 1990). It is similar also to the 513 Ma age obtained for granites of the Serra do Man (Lima et al 1985), the latter probably representing small intrusions or dikes of the Barra do Silva suite.

The Nd evolution of the granites in APT is shown in Fig. 4. The high-K calc-alkalic super-suite presents younger $\mathrm{t}_{\mathrm{DM}} \mathrm{Nd}$ model age (1.3-1.4 Ga) and smaller $\varepsilon N d$ negative values (from -2.7 to -3.5 ) than those of the late-orogenic suites. The São João granite shows a curve intermediate between the two groups $\left(t_{\mathrm{DM}}=1.8 \mathrm{Ga}\right.$ and $\left.\varepsilon \mathrm{Nd}=-3.9\right)$. In general the $\varepsilon \mathrm{Nd}$ of the APT granitoids are higher than the counterparts of the PBT, maybe indicating more crustal involvement in the genesis of the latter ones.

PALEO- TO MESOPROTEROZOIC AGE PLUTONISM OF THE ALTO MOXOTO TERRANE (AMT) The AMT is a Mesoproterozoic Cariris Velhos belt practically not affected by Neoproterozoic magmatism. Accretion of Mesoproterozoic arc volcano-sedimentary sequences and plutonic rocks (Lagoa das ConteNdas complex), terrigenous supracrustal rocks (Sertania complex) and small maficanorthositic complexes that were attached to reworked Paleoproterozoic blocks (the Mulungu microplate, according to Santos 1996) formed it. The structural framework of this terrane is essentially that of Grenville age (Cariris Velhos orogeny), with the main structures trending in NW-SE direction. These structures must be of contractional nature, but the transport sense of the thrust deformation is still unknown. The northwest boundary of the AMT is the already mentioned Serra de Jabitacá nappe, emplaced during the Cariris Velhos orogenic event. The southeast limit is partially coincident with the Congo transcurrent zone, of Brasiliano age.
The oldest plutonic activity of the AMT is a gabbro-anorthosite suite with Fe-Ti ore (Malhada Vermelha suite) that is hosted by Paleoproterozoic rocks, where the relationships are still controversial. Some authors interpret these mafic bodies as enclaves or restites of Transamazonian granites, being therefore Archean or Paleoproterozoic rocks (Melo 1998). The present authors believe that the Malhada Vermelha suite is a extensional anorogenic magmatism cutting Transamazonian blocks within Cariris Velhos belts, comparable to anorthosite complex of Passira in the RCT (see later). They are formed by metamorphic products of gabbro, leucogabbro, noritic gabbro, anorthosite, quartz gabbro, monzogabbro, diorite, quartz diorite, rare troctolite, which include ultramafic lenses, mainly garnet and spinel hornbleNdite, metaperidotite with titano-magnetite concentrations. In the Barro Vermelho complex these rocks occur as xenoliths and restites in trondhjemite, biotite tonalite, quartz monzodiorite, quartz monzonite, granodiorite and monzogranite, interpreted in this paper as Cariris Velhos intrusive rocks.

These Cariris Velhos metagranitoids of the AMT are entirely different from that of the APT. They include the São Pedro metagranitoids and the Riacho das Lajes metatrondhjemites (Santos 1995). The São Pedro metagranitoids are leucocratic with a compositional variation from leucomonzodiorites to leucogranodiorites, and some monzogranites and monzonites. In the Ab-An-Or diagram (Barker 1979) they plot between the granite and trondhjemite fields, with minor incidence in the adamellite field. The mafic minerals are barroisitic amphibole, biotite and occasional clinopyroxene. Accessories include titanite, apatite, allanite, magnetite, clinozoizite, zircon and garnet. The Riacho das Lajes trondhjemites plot dominantly in the quartz dioritic and tonalitic fields in the QAP diagram, as the trondhjemitic calc-alkalic series of Finland, but they fall also in the monzodiorite field showing then similar composition of the anorogenic continental granites of the Corsica (Lameyre \& Bowden 1982). They include clinopyroxene, amphibole, epidote, titanite, magnetite allanite, and apatite, besides scarce biotite, garnet and rutile. In terms of the Barker's parameters, the Riacho das Lajes metatrondhjemites are slightly different from the classical trondhjemites in the world because of the low silica content, very high $\mathrm{Na}_{2} \mathrm{O}$ and an high $\mathrm{FeO} / \mathrm{MgO}$ ratio, and met aluminous character.

The São Pedro metagranitoids show a high LIL-elements enrichment, a strongly depleted pattern of the less incompatible elements, and a characteristic Ba peak, a pattern similar to volcanic arc granites, while the Riacho das Lajes metatrondhjemites are conspicuously Thenriched and $\mathrm{K}_{2} \mathrm{O}, \mathrm{Nb}$ and $\mathrm{Zr}$-depleted (Fig. 2). Between the metagranitoids there are two REE patterns, one with $\Sigma$ REE-depleted and a small LREE/HREE fractionation, and others with strong fractionation patterns without Eu anomaly and a severe depletion in HREE, with normalized levels even down on chondritic values. This last pattern requires garnet in partial melting residue (eclogite residue) or derivation of a moderate fractionated REE source, with dominance of amphibole in residue (Van der Laan \& Wyllie 1992). The REE-depleted pattern suggests a primitive source or epidote or allanite in the residue, which greatly ret aln these elements.

In the $\mathrm{Rb}$ vs. $(\mathrm{Y}+\mathrm{Nb})$ diagram, both São Pedro metagranitoids and Riacho das Lajes metatrondhjemites plot in the VAG field (Fig. 2), but some ratios $(\mathrm{K} / \mathrm{Rb}, \mathrm{Rb} / \mathrm{Sr}, \mathrm{Rb} / \mathrm{Ba})$ are similar to those of oceanic plagiogranites. According to Santos (1995) the alumina vs. silica distribution of the metatrondhjemites is similar to that of classical trondhjemites worldwide (Barker 1979). They plot preferentially in the high alumina field, a few analyses lying also at the low alumina field, a distribution that is similar to that of the Alps trondhjemites (Arth et al. 1978). The $\mathrm{Yb}$ content for a sample with $70 \%$ silica plots in the oceanic field. The distribution of $\mathrm{TiO}_{2}$ and $\mathrm{Al}_{2} \mathrm{O}_{3}$ vs. silica is equivalent to melts produced by partial melting of tholeiites at temperatures above $900^{\circ} \mathrm{C}$ and pressures below $8 \mathrm{kbar}$.

The occurrence of ferro-hastingsite in trondhjemites and the alkalic teNdency of most of this suite can suggest a correlation with the alkalic metagranitoids of Serrinha de Ouricuri, in PBT (M'Rabet et al. 1993). These authors estimated a temperature range between $910^{\circ} \mathrm{C}$ and $700^{\circ} \mathrm{C}$, pressures around 6.7 and $8 \mathrm{kbar}$, corresponding to $25 \mathrm{~km}$ of crust, with source within the lower crust. The generation of these melts leave mafic cumulates resulting in crystallization of $\mathrm{Ca}$-clinopyroxene + Ca-amphibole + oligoclase.

There is no definitive geochronological data for these suites, but some inferences can be made. The São Pedro metagranitoids include mixed populations of zircons where some fractions align in a $\mathrm{U}-\mathrm{Pb}$ discordia of the Cariris Velhos metavolcanic rocks and metagranitoids of both AMT and APT (ca. 1.0 Ga), suggesting their generation in this 
cycle. This conclusion is concordant with the $\mathrm{U}-\mathrm{Pb}$ zircon age of $c a$. 1 , $012 \mathrm{Ma}$ for the hosted metavolcanic rocks of the Lagoa das ConteNdas complex.

\section{A-TYPE PRE-BRASILIANO PLUTONISM AND BRASILI-} ANO GRANITES OF THE RIO CAPIBA-RIBE TERRANE (RCT) This terrane may be a composite terrane, that was preliminary named of Surubim (SUT) and the Serra de Taquaritinga (STT) terranes ( $c f$. Ferreira et al 1997a). The SUT is a Mesoproterozoic and Neoproterozoic belt including a terrigenous metapelitic, metapsamitic and metacarbonate sequence (the Surubim complex), that overlay a metagreywacke, mafic to intermediate metavolcanic and metavolcanoclastic sequence (the Vertentes complex), the latter intruded by Cariris Velhos-age granites and including allochton basement blocks. The STT is a big granitoid-dominated Paleo- to Mesoproterozoic allochton emplaced during the Cariris Velhos orogeny and affected later by Brasiliano shear zones and associated granitoids. The boundary between these terranes is the Serra de Taquaritinga thrust. Paleo- to Mesoproterozoic anorogenic gabbro-anorthositic complex and alkalic granites (from 1.5 to $1.7 \mathrm{Ga}$ ), as well as Grenville-age crustal granites and Neoproterozoic granites have been reported in both terranes (Accioly, A.C., pers. comm.; Sá et al. 1997).

The extension of the anorogenic magmatism in AMT and RCT is still little constrained. The A-type plutonism of Serra de Taquaritinga in the STT (Sá et al. 1997) is characterized by a K-feldspar megacry stic (augen) metagranite with biotite, amphibole and variable amounts of garnet, magnetite, fluorite, titanite and zircon, its composition ranging from granodiorite, through monzogranite, syenogranite to quartz syenite. The metagranite is $\mathrm{Ba}, \mathrm{Th}, \mathrm{Zr}$, Nb and $\mathrm{Y}$-enriched showing a highly fractionated LREE to HREE pattern that has a pronounced negative $\mathrm{Eu}$ anomaly. U-Pb concordia in zircons indicated an age of $1521 \mathrm{Ma}$ for the metagranitoid that intrudes Paleoproterozoic tonalitic orthogneisses (Sá et al. 1997). Both the A-type metagranitoid and its older hosted rock are tectonically emplaced in a volcano-sedimentary belt along the Serra de Taquaritinga thrust. This thrusting episode is of Grenville age (Cariris Velhos cycle), according to a reinterpretation of $\mathrm{Rb}-\mathrm{Sr}$ data of Hama et al. (1978) and field relations that show Brasiliano granite intrusions cutting this orthogneiss allochton.

The massif gabbro-anorthositic complex of Passira, in the eastern part of the SUT (out of the Fig. 1), is composed by a dominant meta-anorthosite, with apatite metadiorite, garnet metagabbro and biotite metagabbro, including concentrations of Fe-Ti ore, and associated diorite-monzonite dike set. Cumulatic, pegmatoid and banded facies are recognized, besides mafic-ultramafic syn-plutonic dikes and lenses. The gabbro-anorthosite complex is $\mathrm{Sr}$ enriched and $\mathrm{Rb}$ depleted and shows different fractionation levels of REE (Accioly et al. 1996; 1997). The gabbro-anorthositic complex and the dioritic dike set cut a block of Paleoproterozoic rocks that was tectonically emplaced in the Vertentes complex. It appears to be associated to an extensional post-Transmazonian episode, according to ages obtained recently by A. C. Accioly (pers. comm.), while the subsequent contractional episode, which is marked by several sheets of crustal granites, is ascribed to the Cariris Velhos orogeny. This last interpretation is inferred by field relationships and considering a $t_{\mathrm{DM}} \mathrm{Sm}-\mathrm{Nd}$ model age of a Brasiliano intrusive granite. Field observations about this Cariris Velhos granitic episode allowed the recognition of biotite granites, biotite-amphibole granites, leucogranites, pyroxene granites and aegirine-augite syenite, quartz syenite and alkali-feldspar granite. The metagranitoids cutting the Passira gabbro-anorthositic complex show trace elements with characteristics similar to that of the lower crustal rocks.

Brasiliano granites intrude rocks of both terranes. We can distinguish: 1) the Moderna oversaturated peralkalic suite, a narrow granitic ridge that stitches the boundary between AMT and RCT along the southwestern portion of the Congo shear zone; and 2) the high-K calc-alkalic and shoshonitic granites of the Serra de Taquaritinga allochtonous terrane (STT). The Moderna suite (Santos \& Vasconcelos 1973) includes ferro-hastingsite, hedenbergite and/or aegirine-augite, sometimes garnet bearing, adamellites, granodiorites and granites. There is no chemical and isotopic data about this suite, which we believe be correlated to peralkalic ultrapotassic plutonism previously described in the PBT-APT boundary.

The Neoproterozoic granitic plutonism in STT involves a high-K calc-alkalic super-suite as well as a shoshonitic syenite suite (Guimaraes 1989; Neves 1996). The high-K calc-alkalic super-suite is well characterized in the Fazenda Nova-Serra da Japecanga complex recently described by Neves \& Vauchez (1995). This complex is formed by two batholiths: 1) the Fazenda Nova batholith, that includes a dioritic to quartz-monzodioritic facies and a porphyritic granitic facies; and 2) the Serra da Japecanga batholith, composed by coarse-grained granite. The two facies of the Fazenda Nova batholith involve the same minerals appearing in different proportions, viz. quartz, plagioclase, $\mathrm{K}$-feldspar, biotite, amphibole, with clinopyroxene also occurring in diorites. Dioritic enclaves are common and sometimes very abundant in porphyritic granites.

The Serra da Japecanga batholith is a coarse-grained biotite amphibole pluton, varying from quartz-syenite to syenogranite in composition. Mafic enclaves are less abundant than the porphyritic granite. The Fazenda Nova batholith is a tabular body similar to Itaporanga batholiths in PBT, but Neves \& Vauchez (1995) were able in recognizing a magmatic stratigraphy, where diorites are superposed by porphyritic granites, which in turn are superposed by coarse-grained granites. According to these authors, field relations and geochemical patterns support a mixing model for the formation of the porphyritic granites, having dioritic magmas and coarse-grained granites as $\varepsilon N d-m e m b e r s$.

The shoshonitic syenite suite is formed by smaller intrusions occurring in the northeastern part of the STT, including the Toritama and Bom Jardim plutons. The Toritama pluton is an over-saturated syenite, presenting porphyritic and equigranular facies, sometimes with rapakivi texture. It includes quartz (up to $10 \%$ ), plagioclase, K-feldspar, clinopyroxene, amphibole and biotite, besides sphene, magnetite, zircon, apatite and allanite. It has a shoshonitic affinity with high $\mathrm{Ba}, \mathrm{Sr}$ and $\mathrm{Th}$, low to moderate $\mathrm{Rb}$ and low $\mathrm{Rb} / \mathrm{Sr}$ ratio (Neves \& Vauchez 1995). The relatively high $\mathrm{MgO}, \mathrm{Ni}$ and $\mathrm{V}$ indicate its mantle-derived character. The compositional similarity of the minerals in syenites and mafic xenoliths and syn-plutonic dikes confirm a common source.

The Bom Jardim and Toritama complexes make up multiple-injection intrusions, including a continuous series varying from mafic syenites and monzonites through mesocratic syenites to leucocratic syenites, besides mafic syenite enclaves and syn-plutonic dikes (Guimaraes \& Silva Filho 1997). They are characteristically $\mathrm{K}_{2} \mathrm{O}$ and $\mathrm{MgO}$ enriched, $\mathrm{K}_{2} \mathrm{O} / \mathrm{Na}_{2} \mathrm{O}>1$, Ba and Sr-enriched and $\mathrm{Nb}$, Ta and $\mathrm{Y}$ depleted that are patterns compatible with those of volcanic arc granites (VAG) (Figs. 2 and 3). In the Santa Cruz do Capibaribe stock charnockites occur associated to gabbro and monzonite.

A Rb-Sr isochron of the Fazenda Nova batholith indicates an age of $632 \mathrm{Ma}$ (McMurry et al. 1987), coherent with ${ }^{40} \mathrm{Ar} /{ }^{39} \mathrm{Ar}$ ages in hornblende of the diorites (587 Ma). The emplacement of the late-kinematic pulse is well constrained by U-Pb zircon concordia of the Toritama pluton, which indicate an age of 592 Ma (Guimarães \& Silva Filho 1997). A composed mineral and whole-rock isochron for the Bom Jardim and Toritama plutons yields an age of $585 \pm 38 \mathrm{Ma}$, with initial ${ }^{87} \mathrm{Sr} /{ }^{86} \mathrm{Sr}$ ratio of 0.70714 , implying a mixed mantle-derived plus crustal-contaminated source. The $\mathrm{t}_{\mathrm{DM}} \mathrm{Nd}$ model ages ranges from 1.8 to $2.0 \mathrm{Ga}$, while the $\varepsilon N d$ values varies from -18.0 to -20.0 (Fig. 4).

DISCUSSION AND CONCLUSIONS In the transverse zone parallel northeast-southwest trending plutonic belts are coherent with the tectonic framework of the terranes. The Mesoproterozoic Cariris Velhos granites (from 1.1 to $0.95 \mathrm{Ga}$ ) are absent or unknown in PBT, but are abundant in APT and AMT, and possibly in RCT, where they are associated to a vigorous flake-dominated collisional episode, which has promoted a very thickened crust. They have short crustal residence times, as revealed by their low negative or chondritic values of $\varepsilon \mathrm{Nd}$, demonstrating the presence of magmas with small crustal contamination. The Cariris Velhos metagranitoids and metatrondhjemites in the AMT show a primitive geochemical signature and are associated to volcanic arc extrusive rocks, revealing also episodes of material accretion. Furthermore in AMT and RCT there is evidence of a pre-Cariris Velhos anorogenic plutonism (from 1.5 to $1.7 \mathrm{Ga}$ ), viz. gabbro-anorthosite and A-type granite, probably associated to extensional and thermally thickened crustal regime (underplating). Therefore they testify substantial horizontal and vertical accretion of new crust in the transverse zone.

The Neoproterozoic granites also present a distribution compatible with the terrane assembly configured in the Cariris Velhos event. Abundant high-K and normal calc-alkalic as well as trondhjemitic magmas invaded the terranes and their boundaries stitched by younger huge peralkalic ultrapotassic granitic and syenitic plutons. This demonstrates continuing influence of the Cariris Velhos NE-SW-trending tectonic framework, now with an emplacement-controlled by a system of anastomosing transtensional shear zones (Jardim de Sá 1994). This tectonic control has permitted to group the granites in suites and super-suites, as in diverse Phanerozoic orogenic belts in the world. 
Distinct geochemical characteristics are reinforced by typical ENd parameters of a plutonism evolving from a normal mantle-derived calc-alkalic super-suite to a slightly peralkalic and trondhjemitic super-suite and finally to an anomalous mantle-derived ultrapotassicshoshonitic super-suite, as demonstrated in $\varepsilon \mathrm{Nd}$ evolutionary curves for the PBT (Fig. 4).

The more abundant super-suite is the high-K-to normal calc-alkalic Itaporanga-Conceição super-suite better exposed in PBT. The high-K calc-alkalic association consists in big tabular complexes including an early basic pulse underplated in the crust, which is somewhat similar to precursor and syn-plutonic basic pulses common, for example, in Circum-Pacific plutonic environment (Regan 1985; Pitcher \& Bussell 1985). However the early character of this basic association and its LILE-enriched character can signify this represents basic volcanic or plutonic rocks of a shoshonitic series, as occurs for example in the British Caledonian granitic Province (Pitcher 1993).

This basic underplated must have been the source of the tonalitic magmas dominant in normal calc-alkalic Concei^ao suite abundant at higher level into the terrane. A trend toward calc-alkalic and subsequently trondhjemitic suites can be invoked, therefore representing a sequence towards less potassic and more $\mathrm{Na}$-enriched magmas with time. The probable association of normal calc-alkalic tonalites and granodiorites, including some gabbroic and dioritic rocks, besides hornbleNdites, preserved as inclusions in tonalites, and possibly representing precursors of the calc-alkalic magmatism, with trondhjemites, suggests a similarity with the gabbro-diorite-tonalite-trondhjemite suite of southwest Finland (Arth et al. 1978). In this unusual calc-alkalic/trondhjemitic association exists a petrographic continuity from hornbleNdite through hornblende gabbro, hornblende-biotite diorite, hornblende-biotite tonalite and trondhjemite. They have been modeled as originated either by fractional crystallization of a gabbroic liquid involving hornblende, plagioclase and biotite as major precipitating phases, or by partial melting of amphibolite, leaving a hornblende-rich residue, amphibolitic or eclogite, leaving an eclogitic residue. So we suggest a hornbleNditic parental magma (from mantle peridotite source) giving place to a calc-alkalic series, since dioritic hornbleNdite through diorite and quartz diorite to granodiorite and granite; and a trondhjemitic series, formed continuously of gabbro, diorite, tonalite to trondhjemite.

The other important super-suite, the late-kinematic peralkalic ultrapotassic and shoshonitic super-suite occurs preferentially at boundaries of the terranes, which are marked by important shear zones that reached deep levels in the lithospheric mantle. These shear zones may have channeled fluids, which were responsible for expressive metasomatism in the mantle. We believe that it is possible to generate pyroxenite and fractionate another series with ultrapotassic characteristics from a mantle peridotite source, although evidence from the Triunfo batholith suggests immiscibility of pyroxenitic and syenitic liquids.

Taking into account the evidence that the most primitive rocks of the ultrapotassic complexes in RCT are already LILE-enriched, HFSE- depleted, have fractionated REE pattern and show $\mathrm{ENd}$ values similar to the syenites, with $t_{\mathrm{DM}} \mathrm{Nd}$ model age ranging between 1.8 and 2.4 Ga, Guimarães \& Silva Filho (1997) consider that these characteristics are representative of the source rock signature. These authors discard the possibility that the $\mathrm{Nd} \mathrm{t}_{\mathrm{DM}}$ model age can be produced by partial melting of a Paleoproterozoic mafic lower crust or by mixing of Archean mafic lower crust with a Brasiliano-age depleted sub-continental lithospheric mantle. Rather, evidence favor the hypothesis that the Bom Jardim and Toritama complexes were generated by partial melting of a Paleoproterozoic lithospheric mantle metasomatised in the Mesoproterozoic, probably during the Cariris Velhos orogeny.

Singular occurrences of mafic syenites and foid-syenites are known in PBT, as the crossite-aegirine-augite-alkali-feldspar syenite (fenite of Farina \& Mello 1970) or the leucite (?) shonkinite with nepheline, olivine and aegirine-augite (Silva Filho et al. 1985). Some of them appear to have a lamprophyric character, viz. sperssatites (Beurlen et al. 1978; Santos \& Brito Neves 1984) and others show features that remind diatremes, despite of a deeper erosion level (e.g. some occurrences in dike sets near PrinceSá Isabel town, and diatreme xenoliths in the Caboclo syenite of the Riacho do Pontal belt in the External domain). This context can indicates relationship between a probable lamprophyric activity and the shoshonitic/ultrapotassic super-suite, the same as the appinitic (lamprophyric) and shoshonitic connection postulated by Fowler (1988) and Fowler \& Henney (1996) for the Ach'Uaine hybrid appinites and associated granites and syenites from northern Scotland. According to these authors the geochemical patterns of these rocks are consistent with early fractional crystallization of clinopyroxene and biotite from a shoshonitic magma, driving the evolving magma to a lamprophyric composition. Subsequent crystal fractionation feldspar-dominated with minor contamination is required for granite derivation. They concludes that the distinctive $\mathrm{Ba}-\mathrm{Sr}$ enrichment and trace element characteristics of these granitoids are derived from a heterogeneous mantle component, rather than from the continental crust and that this magmatism may represent a significant juvenile accretion to the crust.

The accretion related to the Brasiliano suites and super-suites, which is characteristically controlled by an extensional or transtensional regime, appears to be essentially a dispersion-like phenomena, considering a possible appinitic-lamprophyric associated series, which is always present in zones of thickened crust (Pitcher 1993). In other words, the thickening of the crust that occurred during the Cariris Velhos orogeny would have prepared the tectonic environment for the development of the vigorous Brasiliano-age vertically-dominated accretion. Therefore, the granite formation in the Transverse Zone represents significant successive events of crustal growth in the evolution of the Borborema Province.

Aknowledgements The authors would like to express their gratitude to anonymous reviewers, as well as A.N. Sial and V.P. Ferreira, whose criticism and suggestions greatly improved this article.

\section{References}

Accioly, A.C.; McReath, I.; Santos, E.J.; Mello, C.B.M.; Guimarães, I.P. 1996. Química mineral e petrografia de fácies do Complexo Anortossíticó de Passira-PE. In: SBG, Congr. Bras. Geol., 39, Res., 2:3-5.

Accioly, A.C.; Santos, E.J.; McReath, I.; Guimarães, I.P.; Mello, C.B.M. 1997. O meta-anortosito maciço Proterozoícó de Passira-PE e rochas associadas. In: SBG, Simp. Geol. Nordeste, 17, Res Exp., 229-333.

Almeida, F.F.M; Leonardos Jr., O. H.; Valen?a, J. 1971. Review on granitic rocks of Northeast South America. IUGS, Comm. Study Geol. Docum., 41 p.

Arth, J.G.; Barker, F; Peterman, Z.E.; Friedman, I. 1978. Geochemistry of the gabbro-diorite-tonalite-trondhjemite of the southwest Finland and its implications for the origin of tonalitic and trondhjemitic magmas. Jour. Petrol., 19:289-316.

Barbarin, B. 1990. Granitoids: main petrogenetic classifications in relation to origin and tectonic setting. Geol. Journ., 25:227-238.

Barbarin, B. 1996. Genesis of the two main types of peraluminous granitoids. Gealog 24:289-384.

Barker, F. 1979. Trondhjemites, dacites, and related rocks. Amsterdam. Elsevier Sci. Puhl. Co. 659p.

Barr, S.M.I 990. Granitoid rocks and terrane characterization: an example from the northern Appalachian Orogen. Geol. Journ. 25:295-304.

Beurlen, H.; Sial, A.N.; Brito Neves, B.B. 1978. Considerafoes sobre a geologia da area entre Piancó e Cantingueira-PB. In: SBG, Congr. Bras. Geol., 39, Anais, 1·58-68.

Boriani, A.; Origoni, G.E.; Pinarelli, L. 1995. Paleozoic evolution of southern Alpine crust (northern Italy) as indicated by contrasting granitoid suites. Lithos, 35:47-63

Brasilino, R.G.; Sial, A.N.; Ferreira, V.P. 1997. Subcrustal emplacement of the Conceicao das Creoulas pluton of Alto Pajeii terrane, NE Brazil: evidence from magmatic epidote and hornblende mineral chemistry. In: Int. Symp. Gran. Assoc. Mineral. 2, Ext. Abst., 181-182.
Brasilino, R.G.; Sial, A.N.; Lafon, J.M. 1998. Magmatic epidote, hornblende barometric estimates and emplacement of the Concei?ao das Creoulas pluton, Alto Pajeú terrane, NE Brazil. Anais Acad. Bras. Ci. (accepted for).

Brito Neves, B.B.; Cordani, U. 1991. Tectonic evolution of South America during the Late Proterozoic. Precamb. Res., 53:23-40.

Brito Neves, B.B.; Van Schmus, W.R.; Santos, E.J.; Campos Neto, M.C.; Kozuch, M. 1995. O evento Cariris Velhos na Província Borborema: integração de dados, implicates e perspectivas. Rev. Bras. Geoc., 25:279-296.

Campos Neto, M.C.; Brito Neves, B.B.; Bittar, S.M.B. 1994. Domínio tectônicó Rio Pajeú: orogeneses superpostas no ciclo Brasiliano/Panafricano. Rel. Cient., FAPESP, Proc. Geoc. 92/2079, 62p. (unpubl.).

Castro, A.; Moreno-Ventas, I.; De La Rosa, J. D. 1991. H-type (hybrid) granitoids: a proposed revision of the granite classification and nomenclature. Earth-Sci. Rev. 31:237-253.

DePaolo, D.J. 1981. A neodymium and strontium isotopic study of the Mesozoic calc-alkaline granitic batholiths of the Sierra Nevada and Peninsular Rangers, California. Jour. Geophys. Res. 86:10470-10488.

Evensen, N.M.; Hamilton, P.J.; O'Nions, R.K. 1978. Rare-earth abundances in chondrite meteorites. Geoch. Cosmoch. Acta, 42:1199-1212.

Farina, M.; Melo, Z.F. 1970. Fenito com mineralizafao plumbo-cuprifera em Catingueira -Paraíba. Min. Met al., 306:225-228.

Ferreira, V. P. 1991. Petrology and geochemistry of the Late Proterozoic ultrapotassic peralkaline Triunfo batholith and related dikes, State of Pernambuco, Northeast Brazil, University of Georgia, Athens, Georgia, Ph.D. dissertation, 269p.

Ferreira, V. P.; Sial, A. N. 1986. The peralkalic magmatism in the Precambrian Cachoeirinha-Salgueiro fold belt, Northeast Brazil: geochemical aspects. Rev. Bras Geoc. 16:73-85. 
Ferreira, V.P.; Sial, A.N., Whitney, LA. 1992. Imiscibilidade de liquidos como principal processo magmatIcó na formafao de sienitos peralcalinos ultrapotassIcós e piroxenitos associados no Precambriano do Nordeste do Brasil. An. Acad. Bras. CL, 64:367-382.

Ferreira, V.P; Sial, A.N.; Witney, J.A. 1994. Large-scale silicate liquid immiscibility: a possible example from northeastern Brazil. Lithos, 33:285-302.

Ferreira, V.P.; Sial, A.N., Fallich, A.E., Cruz, M.J.M. 1995. Amphibole-rick clots in calc-alkalic granitoids and their mafic microgranular enclaves from two fold belts, NE Brazil. In: III Hutton Symposium. The origin of granites and related rocks. U.S. Geological Survey. 1129:p.49.

Ferreira, V.P; Sial, A.N.; Santos, E.J.; Jardim de Sa, E.F.; Medeiros, V.C. 1997a. Granitoids in the characterization of terranes: the Borborema Province, northeastern Brazil. In: Ferreira, V.P. \& Sial, A.N. (eds.) II Int. Symp. Gran. Assoc. Mineral., ExteNded Abst., p. 197-201, Salvador.

Ferreira, V.P; Sial, A.N.; Long, L.E.; Pin, C. 1997b. Isotopic signatures of Neoproterozoic to Cambrian ultrapotassic syenitic magmas, Northeastern Brazil: evidence for an enriched mantle source. Intern. Geol. Review, 39:660-669.

Ferreira, V.P., Sial, A.N., Pessoa, R.J.R., 1997c. Fontes distintas para magmas ultrapotassIcós na Zona Transversal, NE do Brasil: evidencias a partir de isdtopos de O e Nd. Cong. Bras. Geol, 6, Anais, 2:746-748.

Fetter, A.; Van Schmus, W.R.; Santos, T.S.; Arthaud, M.; Nogueira Neto, J. 1997. Geologic history of Cear£ State: NW Borborema Province, NE Brazil. South American Symp Isotope Geol., ExtcNd. Abstr. 112-114.

Fowler, M.B. 1988. Ach'uaine hybrid appinite pipes: evidence for mantle-derived shoshonitic parent magmas in Caledonian granite genesis. Geology, 16:1026-1030.

Fowler, M.B.; Henney, P.J. 1996. Mixed Caledonian appinite magmas: implications for lamprophyre fractionation and high Ba-Sr granite genesis. Ctmtrih. Mineral. Petrol. 126:199-215.

Guimarães, 1.1989. The petrological evolution and tectonic associations of the Bom Jardim Complex, Pernambuco State, NE Brazil. University of London, Ph.D. dissertation, 423p.

Guimarães, I.P.; Silva Filho, A.F. 1997. Nd and Sr isotope and U/Pb geochronological data constraints for the evolution of the shoshonitic Brasiliano Bom Jardim and Toritam complexes: Evidence for a vertically layered enriched mantle in northeast Brazil ? In: South Amer. Symp. Isot. Geol., Ext. Abst. 129-130, Campos do Jordao.

Hama, M.; Mello, A. A.; Costa, A.C.; MeNdes, V. A. 1978. Geocronologia de area do Projeto Agreste de Pernambuco. In: SBG, Cong. Bras. Geol., 30, Anais., 1:349-350, Recife.

Harris, N.B.W.; Inger, S. 1992. Trace element modelling of pelite-derived granites. Cant rib. Mineral. Petrol., 110:46-56.

Jardim de S5, E.F. 1994. A Faixa Serid6 (Província Borborema, NE do Brasil) e o seu significado geodinâmico na Cadeia Brasiliana/Pan-Africana. UnB, Brasilia, doctoral dissertation, $803 \mathrm{p}$

Jardim de Sá, E.F.; Macedo, M.H.F.; Fuck, R.A.; Kawashita, K. 1992. Terrenos proterzóicos na Província Borborema e a margem norte do Cráton do São Francisco. Rev. Bras. Geoc., 22:472-480.

Jardim de Sá, E.F.; Medeiros, W.E; Castro, D.L. 1997. Contribuicao da gravimetria aos modelos de estruturacao crustal da Província Borborema, Nordeste do Brasil. Simp. Geol. Nordeste, 17, Res. Expand., 15:352-357, Fortaleza.

Kozuch, M.; Bitar, S.M.; Van Schmus, W.R.; Brito Neves, B.B. 1997. Late proterozoic and middle neoproterozoic magmatism in the zona transversal of Borborema Province, Brazil. In: SBG, Simp. Geol. Nordeste, 17, Res Exp., 47-50., Fortaleza

Lameyre, J.; Bowden, P. 1982. Plutonic rock types series: discrimination of various granitoid series and related rocks. Jour. Vole. Geoth. Res., 14:169-186.

Leite, P.R.B.; Lima, E.S. 1997. Caracterização geoquímica de granitóides proterzóicos na Folha Monteiro, terrene Alto Pajeú, nordeste do Brasil. In: SBG, Simp. Geol. Nordeste, 17, Res Exp., 282-287, Fortaleza

Lima, E.S.; Bittar, S.M.B.; Accioly, A.C.A.; Vannucci; R; Mazuchelli, M. 1996. Caracterização petrogene'tica das rochas meta-vulcanicas da faixa Pianc6-Alto Brfgida, (folhaSerraTalhada), NE brasileiro. In: SBG, Cong. Bras. Geol., 39, Anais, 6:44-46, Salvador

Lima, M.I.C.; Gava, A.; Fernandes, P.E.C.A.; Pires, J.L.; Siga Jr., 0. 1985. Projeto ferro titanado de Floresta. Minerios de Pernambuco/ Radambrasil, vol. I-Geologia, 314p. (unpubl.).

M'Rabet, S.; Bonin, B.; Barbarin, B. 1993. Rock-forming mineral evolutionary trends within (per)alkaline complexes Cachoeirinha- Salgueiro foldbelt, Pernambuco-Paraíba, Northeast Brazil, In: Sial, A.N.; Ferreira, V.P.; Chaves, N.S.; Gorki, M. (Eds.)-Magmatismo granítico e mineralizações associadas, Acad. Bras. Ci., Res. Exp. 71-14

Mariano, G.; Sial, A.N. 1988. Evidence of magma mixing in the Itaporanga batholith Northeastern Brazil. Rendic. Soc. Ital. Mineral. Petrol., 43:555-567.

Mariano, G.; Sial, A.N. 1990. Coexistence and mixing of magmas in the late precambrian Itaporanga batholith, state of Paraíba, northeastern Brazil. Rev. Bras. Geoc., 20:101-110

Mariano, G.; Sial, A.N. 1993. High K-calc-alkalic vs. shoshonitic granitic magmatism in Northeast Brazil. In: Sial, A.N.; Ferreira, V.P. (Eds.) Workshop on Granitic Magmatism and Associated Mineralizations, An. Acad. bras. Ci., 65:119-130.

McMurry, J.; Long, L.E.; Sial, A.N. 1987. Petrology and isotopic systematics of magma mushes: some porphyritic granitoids of northeastern Brazil. Rev. Bras. Geoc., 17:473-480

Medeiros, V.C. 1995a Comparacões geoquímicas entre granitóides do Domínio da zona transversal, Nordeste do Brasil. Rev. Bras. Geoc., 25:333-342.

Medeiros, V.C. 1995b. Sensoriamento remoto e petrologia de granitóides brasilianos no Domínio da zona transversal, Nordeste do Brasil. Centre de Tecnologia, Universidade Federal de Pernambuco, M.Sc. thesis, 149p. Recife

Medeiros, V.C., Jardim de Sa, E.F., Macedo, M.H.F., Souza, Z.S. 1993. Estruturas tangenciais e metagranitóides transamazonIcós na Faixa Salgueiro-Cachoeirinha a oeste de Parnamirim-PE. In: Simp. Geol. Nordeste, 15, Natal. Res. Natal: SBG, $284-287$.

Melo, O.O. 1998. Petrologia e geoquímica das rochas gabro-anortosfticas e mineralizações de Fe e Ti associadas de Barro Vermelho-Custódia-PE, Nordeste do Brasil. Centre Tecnologia/UFPE, doctoral disertation, 207p. Recife
Melo, S.C.; Guimarães, I.P.; Lima, E.S.; Silva Filho, A.F.; Vannucci, R.; Mazzuchelli, M. 1995. Caracterizaçãao geoquímica do Complexo Prata: magmatismo bimodal pós tectonicó do Proterozoicó Superior no NE do Brasil. In: Congr. Geoq. Países Ling. Portug. 3, CD-ROM. 4p

Melo, S.C.; Guimarães, I.P.; Silva Filho, A.F.; Macambira, M.J.B.; Lima, E.S. 1996. Geochemical and $\mathrm{Rb} / \mathrm{Sr}$ data of the neoproterozóico bimodal anorogenic magmatism in the Borborema Province, NE Brazil: the Prata Complex. In: SBG, Cong. Bras. Geol., 39, Res. Exp., 6:607-610.

Neves, S.P. 1987. Granitic rocks with trondhjemitic affinities and associated peralkaline granites in the Serrita stocks. Int. Symp. Gran. Assoc. Mineral., 1, Abst., 169-171.

Neves, S.P. 1996. Étude des relations entre magmatisme et zones de cisaillement lithosphériques: exemple des decrochements de Pernambuco et Fazenda Nova - 6 tat de Pernambuco, Bre'sil. Univers. Montpellier II, France., Doctoral Dissertation, 243p.

Neves, S.P.; Vauchez, A. 1995. Sucessive mixing and mingling of magmas in a plutonic complex of Northeast Brazil. Lithos, 34:275-299.

Pearce, J.A 1996. An review about sources and tectonic setting of granitic rocks. Episodes, 19:120-125.

Pearce, J. A., Hams, N.B.W; Tindle, A.G. 1984. Trace element discrimination diagrams for the tectonic interpretation of granitic rocks. Jour. Petrol., 25:956-983.

Pitcher, W.S. 1985. A multiple and composite batholith. In: Pitcher, W.S.; Antherton, M.P.; Cobbing, E.J.; Beckinsale, R.D. (Eds.). Magmatism at a plate edge: the Peruvian Andes. Blackie \& Sun Ltd. 93-101.

Pitcher, W.S. 1993. The nature and origin of granite. Blackie Academ. Profess., 321 p.

Pitcher, W.S.; Bussell, M.A. 1985. Andean dyke swarms: andesite in synplutonic relationship with tonalite. In: Pitcher, W.S.; Antherton, M.P.; Cobbing, E.J.; Beckinsale, R.D. (Eds). Magmatism at a plate edge: the Peruvian Andes. Blackie \& Sun Ltd. 102-107.

Regan, P.P. 1985. The early basic intrusions. In: Pitcher, W.S; Antherton, M.P.; Cobbing, E.J.; Beckinsale, R.D. (Eds.). Magmatism at a plate edge: the Peruvian Andes. Blackie \& Sun Ltd. 72-89.

Reyes, C.; Sial, A.N.; Ferreira, V.P. 1996. Estudo preliminar petro!6gIcó e geoqufmIcó do batolito Pajeú, terreno Alto Pajeú, Pernambuco. In: SBG, Cong. Bras.Geol., 39, Res., 6:349-553, Salvador

Roberts, M.P.; Clemens, J.D. 1993. Origin of high-potassium, calc-alkaline, I-type granitoids. Geology, 21:825-828.

Sa, J.M.; Bertrand, J.M.; Leterrier, J. 1997. Geocronologia U-Pb e geoquímica de ortognaisses Paleo e MesoproterozdIcós da regiao de Taquaritinga-PE. In: SBG, Simp. Geol. Nordeste, 17, Res Exp., 108-112.

Santos, E.J. 1995. O complexo granítico Lagoa das Pedras: acrescao e coliSão na regiao de Floresta (Pernambuco), Província Borborema. Inst de Geociências, Universidade de São Paulo. Doctoral dissertation. 219p. São Paulo

Santos, E.J. 1996. Ensaio preliminar sobre terrenos e tectonica acrescionaria na Província Borborema In: SBG, Congr. Bras.Geol., 39, Res., 6:47-50.

Santos, E.J.; Vasconcelos, M.L. 1973. Caracterfsticas dos granitóides de tipo Moderna do Lineamento Pernambuco. Min. Met al. 339:28-33

Santos, E.J.; Vasconcelos, M.L. 1977. Plutonismo granítico nos arredores do Sftio dos Nunes, Pernambuco, e seu significado no contexto da granitizafao brasiliana do Nordeste. Rev. Bras. Geoc., 7:58-72.

Santos, E.J.; Brito Neves, B.B. 1984. Província Borborema. In: Almeida, F.F.M.; Hasui, Y. (Eds.), O Pre-Camhriano do Brasil. Edgard Blucher, 123-186.

Santos, E.J.; Brito Neves, B.B. 1993. Petrogenetic and tectonic setting of the Lagoa das Pedras magmatism, Floresta, state of Pernambuco, Borborema Province, Northeast Brazil. In: Sial, A.N. \& Ferreira, V.P. (eds.) Workshop MAGMA, Anais Acad. Bras. $C L, 65: 131-139$.

Santos, E.J., Medeiros, V.C. 1997. Constraints from granitic plutonism on proterozoic crustal growth of the zona transversal domain, Borborema Province, NE Brazil. In: Ferreira, V.P. \& Sial, A.N. (eds.), II Int. Symp. Gran. Assoc. Mineral., ExtcNded. Abstr. 237-239, Salvador

Santos, E.J.; Brito Neves, B.B.; Van Schmus, W.R. 1995. O Complexo Granítico Lagoa das Pedras: acresção e colisão na regiao de Floresta (Pernambuco), Província Borborema. In: SBG, Simp. Geol. Nordeste, 16, Anais.. 2:401-406, Natal

Santos, E.J.; Oliveira R.G; Paiva, I.P. 1997. Terrenos do Domínio Transversal da Província Borborema: controles sobre acresjao e retrabalhamento crustais ao sul do Lineamento Patos. Simp. Geol. Nordeste, 17, SBG, Resumos Expandidos., 41-44, Fortaleza

Sial, A.N. 1986. Granite-types in northeastern Brazil: current knowledge. Rev. Bras. Geoc 16:52-72.

Sial, A.N. 1987. Granitic rocks of northeast Brazil. Inter. Symp. Granites Assoc. Mineraliz Ext. Abst., 61-69, Salvador

Sial, A.N. 1993. Contrasting met aluminous magmatic epidote-bearing granitic suites from two precambrian fold belts in Northeast Brazil. In: Sial, A.N. \& Ferreira, V.P. (eds.) Workshop Magma, Anais Acad. Bras. Ci., 65:141-162.

Sial, A.N; Ferreira, V.P. 1991. Granitóides calci-alcalinos com epidoto, no domínio estrutural-central, Nordeste do Brasil. Simp. Geol. Nordeste, SBG, Res. 116-118, Fortaleza

Sial, A.N.; Mariano, G.; Ferreira, V.P. 1989. Isotopic geochemistry of Brasiliano age, coarsely porphyritic, K-calc-alkalic granitoids and associated K-diorites Northeast Brazil. II Cong. Bras. Geoq., 2, 229-239, Rio de Janeiro

Sial, A.N.; Ferreira, V.P.; Santos, E.J. 1997. Magmatic epidote-bearing granitoids and ultrapotassic magmatism of the Borborema Province, northeast Brazil. II Intern. Symp. Gran. Assoc. Mineral., Excur. Guide. 35-54, Salvador

Sial, A.N., Pessoa, D.A., Villarroel, H.S., Lima, E.S., Rodrigues da Silva, M.R., Castro, C. de, Borba, G.S., 1981. Petrologia e geoquímica do bat61ito de Bodoc6 e "stocks" de Serrita, Pernambuco. X Simp. Geol. NE, SBG, pp. 388-401, Recife

Silva Filho, A.F.; Guimarães, I.P. 1990. Geologia das rochas ultrapotassicas da regiao de Salgueiro, PE. Cong. Bras. Geol., 36, SBG, Anais, 4:1752:1763, Natal

Silva Filho, A.F.; Guimarães, I.P.; Thompson, R.N. 1993. Shoshonitic and ultrapotassic Proterozoic intrusive suites in the Cachoeirinha-Salgueiro belt, NE Brazil: a transitional from collisional to post-collisional magmatism. Precamh. Res. 62:323-342.

Silva Filho, M.A.; Nesi, J.R.; MeNdes, V.A. 1985. Projeto Cachoeirinha: Relatório final integrado. Recife. DNPM/CPRM. 4v. (unpubl.). 
Silva, J.M.R.; Lima, E.S.; Sales, A.O.; Moura, C.A.V.; Scheller, T. 1996. Datacao pelo me'todo de evapora9ao de $\mathrm{Pb}$ de granites cinza foliados da infra-estrutura da Faixa Pajeú-Paraíba. Congr. Bras.Geol., 39, SBG, Res., 6:519-521, Salvador

Skjerlie, K.P; Johnston, A.D. 1996. Vapour-absent melting from 10 to $20 \mathrm{kbar}$ of crustal rocks that contain multiple hydrous phases: implications for anatexis in the deep to very deep continental crust and active continental margins. Jour. Petrol., 37:661-691.

Trompette, R. 1994. Geology of Western Gondwana (2000-500 Ma): Pan-African-Brasiliano Aggregation of South America and Africa. A.A.Balkema Publishers, 350p

Van Per Laan, S.R.; Wyllie, P.J. 1992. Constraints on Archean trondhjemite genesis from hydrous crystallization experiments on Nuk gneiss at 10-17 kbar. Jour. Geol., $100: 57-68$.
Van Schmus, W.R.; Brito Neves, B.B.; Hackspacher, P.; Babinski, M. 1995. U/Pb and $\mathrm{Sm} / \mathrm{Nd}$ geochronologic studies of the Eastern Borborema Province, Northeastern Brazil: initial conclusions. Jour. South Am. Earth Sci. 8:267-288.

Wanderley, A.A.; Veiga Junior., J.P.; Santos, E.J. 1992 O complexo Irajaí no contexto evolutive da Provmcia Borborema. Cong. Bras. Geologia, 37, SBG, 1:302-304, Recife

Windley, B. 1992. Proterozoic collisional and accretionary orogens. In: Condie, K.C. (Eds.). Proterozoic crustal evolution. Elsevier, 419-446.

Manuscrito A-1054

Recebido em 15 de Janeiro de 1998

ReviSão dos autores em 18 de julho de 1998 ReviSão aceita em 30 de agosto de 1998 